\title{
Developmental and Neural Regulation of a Subsarcolemmal Component of the Rat Neuromuscular Junction
}

\author{
Stephanie H. Astrow, Lee A. Sutton, and Wesley J. Thompson \\ Center for Developmental Biology and Department of Zoology, University of Texas, Austin, Texas 78712
}

\begin{abstract}
We have generated a monoclonal antibody, designated mAb $3 G 2$, which reacts with a subsarcolemmal component of the neuromuscular junction in adult rats. mAb 3 G2 immunoreactivity lies beneath and between the ACh receptor-rich synaptic gutters, around the sole plate nuclei, and at/near sarcomeric Z-disks in the vicinity of the synapse. Localization of $\mathrm{mAb} 3 \mathrm{G} 2$ immunoreactivity to neuromuscular junctions begins postnatally and gradually increases to adult levels. The establishment of this synaptic localization is neurally regulated, as neonatal denervation prevents its occurrence. In adults, denervation results in a loss of synaptic immunoreactivity that returns upon reinnervation. The antigen is also found at the myotendinous junction; its localization here is innervation independent. mAb $3 G 2$ recognizes a $41 \mathrm{kDa}$ protein on immunoblots of extracts of newborn muscle. Based on its distribution within muscle fibers, its developmental and neural regulation, and its molecular weight, the protein recognized by $\mathrm{mAb} 3 \mathrm{G} 2$ can be distinguished from other known postsynaptic proteins. Its neural dependence and developmental regulation suggest that it may participate in synaptic stabilization, perhaps as the intracellular component in a chain of proteins that serve to tether the nerve terminal to the perijunctional region of the muscle fiber.
\end{abstract}

The neuromuscular junction is the site where skeletal muscle fibers receive their innervation from motor axons of the CNS. A number of morphological specializations of the postsynaptic muscle fiber characterize this synaptic site (Salpeter, 1987). The terminal processes of the motor axon occupy depressions in the surface of the muscle fiber called synaptic gutters. The membrane within these gutters is extensively invaginated, forming the so-called postsynaptic folds. Underneath the membrane at the peaks of the folds (and, to a lesser extent, in the troughs) lies an electron-dense material, the postsynaptic density, which is apparently attached to a still deeper network of cytoskeletal filaments. There are also accumulations of nuclei (the sole plate nuclei) in the sarcoplasm just beneath the junction.

The neuromuscular junction is also the site of numerous biochemical specializations (Salpeter, 1987; Froehner, 1991). Nic-

\footnotetext{
Received Aug. 21, 1991; revised Oct. 11, 1991; accepted Oct. 18, 1991.

We thank Drs. J. Herz, M. Poenie, G. Pollak, K. Wang, and H. Zakon for helpful comments on the manuscript, Drs. R. Beach and J. Venuti for copyediting, and Janet Young for assistance in preparing schematic illustrations. This work was supported initially by a grant from the National Institutes of Health (NS20480) and in later stages by a grant from the National Science Foundation (BNS-9009682).

S.H.A. was supported by a postdoctoral fellowship from the Muscular Dystrophy Association and an NICHD training grant (T32 HD07296 GT) to the Center for Developmental Biology.

Correspondence should be addressed to Stephanie H. Astrow, Department of Zoology, University of Texas, Austin, TX 78712.

Copyright (c) 1992 Society for Neuroscience $0270-6474 / 92 / 121602-12 \$ 05.00 / 0$
}

otinic ACh receptors (AChRs) are highly concentrated at the peaks of the postsynaptic folds within the junction. The receptors are associated with submembranous proteins (most notably, a $43 \mathrm{kDa}$ protein) that may serve to limit the mobility of the receptors within the sarcolemma (Froehner, 1991). Sodium channels are also concentrated in the junction, specifically in the sides and bottoms of troughs formed by the postsynaptic folds; these sodium channels exist in close association with the protein ankyrin (Flucher and Daniels, 1989). A number of cytoskeletal proteins and focal adhesion proteins are concentrated in the junction, where they are believed to maintain the postsynaptic folds, anchor the muscle fiber to the extracellular matrix, and provide structural integrity to the fiber during muscle contractions (Shear and Bloch, 1985).

Although recent work has yielded a great deal of information regarding the nature of the morphological and biochemical specializations found at the neuromuscular junction, we still lack a complete picture of how this structure is assembled and maintained. A number of studies have demonstrated a crucial role for the motor nerve in establishing the junctional specializations of the postsynaptic muscle fiber. For example, the site where the junction will ultimately reside is determined by the location of initial nerve contact (Bennett and Pettigrew, 1974). Apparently, this nerve contact leaves a persistent imprint on the muscle fiber, as many of the features of a mature junction differentiate at a site contacted only briefly by a motor neuron, provided that the muscle itself is stimulated to activity (Lomo, 1987).

Given the obvious interdependence of nerve and muscle for the establishment of the neuromuscular junction, one approach toward furthering our understanding of the development and maintenance of this synapse is to identify junction-specific muscle proteins that are neurally regulated. In this article, we report the identification of such a protein. The molecular mass of this protein $(41 \mathrm{kDa})$ taken together with its solubility characteristics and immunocytochemical profile argues that it is a novel component of the neuromuscular junction. Our observations regarding the timing of its localization to the synapse relative to other developmental events suggest that this protein may play a role in the stabilization of synaptic contacts.

\section{Materials and Methods}

\section{Animals and surgical procedures}

Rats were obtained from a closed colony of the Wistar strain established from stock from Timco Labs (Houston, TX) in 1979. Timed pregnancies were obtained by pairing males and females overnight. The day immediately following pairing was defined as embryonic day 0 (E0), and pregnancy was confirmed on the basis of significant weight gain on the following days. Some rat fetuses were rendered aneural by injection with $\beta$-bungarotoxin on E14. This procedure, originally developed by Harris (1981), has been described in detail previously (Condon et al., 1990b). 
The right soleus muscle of some adult rats was denervated either by unilateral tibial nerve resection or by nerve crush. These animals were anesthetized with ether, and the right tibial nerve was exposed within the popliteal fossa. In cases where no reinnervation was desired, the nerve was ligated with 6-0 suture and approximately $1 \mathrm{~mm}$ of nerve was resected distal to the ligature. In cases where reinnervation was desired, the tibial nerve was crushed three times between the tips of a pair of fine forceps (Dumont \#5). The intramuscular wound and skin incision were closed with sutures. Upon death, the right soleus muscle and its nerve were dissected and the muscle connected to a tension transducer. The extent of reinnervation was determined by comparing the amount of tension generated by nerve stimulation to the tension obtaincd by stimulating the muscle directly.

\section{Preparation of immunogen}

Membrane vesicles were prepared from adult and neonatal rat muscle. Adult animals (300-350 gm) were killed with ether, and the hindlimb muscles were dissected in chilled Ringer's solution (Rees, 1978). On average, $25 \mathrm{gm}$ of trimmed muscle was obtained from each individual. The muscles from several animals were pooled, blotted dry, weighed, frozen in liquid $\mathrm{N}_{2}$, and stored at $-20^{\circ} \mathrm{C}$ until use. For neonatal animals, a $1 \mathrm{~mm}$ piece of the sciatic nerve was resected bilaterally from etheranesthetized pups on postnatal day 1 (P1), P2, or P3. The wounds were closed and the animals were returned to their mothers. Three to four days following surgery, the pups were held at $-20^{\circ} \mathrm{C}$ for several minutes until anesthetized and were then decapitated. Hindlimb musculature below the level of the knee was dissected out in chilled Ringer's. On average, $0.15 \mathrm{gm}$ of muscle was obtained from each animal. The muscles from several animals were pooled and frozen as for adult animals. All subsequent steps were carried out at $0-4^{\circ} \mathrm{C}$.

Approximately $50 \mathrm{gm}$ of frozen adult muscle was chopped into fine pieces with a razor blade. The chopped muscle was processed through a blender and centrifuged at low speed to remove particulate matter. The pellet obtained after high-speed centrifugation was washed and repelleted several times following published methods (Seiler and Fleischer, 1982). Muscle cell plasma membranes were then prepared by centrifugation through a $41 \%, 32 \%$, and $17 \%(w / v)$ sucrose step gradient (Hall et al., 1988). Fractions containing protein were identified by $\mathrm{OD}_{280}$, pooled, diluted 10 -fold by the addition of $10 \mathrm{~mm}$ triethanolamine hydrochloride, $\mathrm{pH} 7.4$ (TEA buffer), and collected by centrifugation (Hall et al., 1988). The final pellet was resuspended in TEA buffer and stored at $-80^{\circ} \mathrm{C}$ until use. Neonatal membranes were isolated following the same procedure, except that $5 \mathrm{gm}$ of starting material were used, and the volumes of the buffers were reduced proportionally. The concentration of protein in each sample was determined using a Bradford protein assay (Bio-Rad, Richmond, $\mathrm{CA}$ ). On average, $5-15 \mathrm{mg}$ of protein was obtained per $50 \mathrm{gm}$ of adult muscle and $1 \mathrm{mg}$ of protein per $5 \mathrm{gm}$ of neonatal muscle.

\section{Production of monoclonal antibodies}

The procedure used was that of Hockfield (1987 and personal communication). Briefly, neonatal BALB/c mouse pups were given intraperitoneal injections of the adult rat membrane preparation $(0.3 \mathrm{mg} / 50$ $\mu \mathrm{l}$ TEA buffer, $\mathrm{pH}$ 7.4) every other day from the day of birth through day 14 , in an attempt to induce tolerance to proteins present in adult membranes. At 4 weeks of age, these mice were immunized in each of the hind footpads with the neonatal rat membrane preparation $(0.5 \mu \mathrm{g}$ in $10 \mu$ l of TEA buffer) emulsified 1:1 with Freund's complete adjuvant. This immunization was continued at $4 \mathrm{~d}$ intervals, for a total of four injections. On day 16 , the animals were anesthetized with ether, killed by cervical dislocation, and dissected to remove the inguinal and popliteal lymph nodes. Isolated lymphocytes were fused with NS-1 myelomas and plated onto macrophages in 96 well plates. Hybridomas were selected in hypoxanthine, aminopterin, and thymidine medium (Littlefield, 1964). Hybridoma supernatants were screened by immunocytochemistry on cryostat sections taken through neonatal hindlimb musculature. $\mathrm{mAb} 3 \mathrm{G} 2$ was stabilized by three rounds of cloning by limiting dilution. For immunoblots, mAb $3 \mathrm{G} 2$ supernatant was concentrated and dialyzed into $3.0 \mathrm{M} \mathrm{NaCl}, 1.5 \mathrm{M}$ glycine, $\mathrm{pH} 8.9$, using an Amicon ultrafiltration cell (W. R. Grace, Danvers, MA), and then subjected to affinity chromatography using a protein $\mathrm{A} / \mathrm{G}$ column (Schleicher and Schuell, Keene, NH). This concentrated, purified supernatant contained $1.4 \mathrm{mg}$ of protein per $\mathrm{ml}$.

\section{Histochemistry and immunocytochemistry}

Frozen sections. Cryostat sections, $2-10 \mu \mathrm{m}$ in thickness, were prepared and processed for immunocytochemistry with mAb 3G2 (at 1:10 dilution) or mAbs to isoforms of sarcomeric myosin heavy chain (SMHC) using standard techniques (Condon et al., 1990a). The mAbs to myosin used in this study, 4A.841 (specific for slow SMHC) and N1.551 (specific for neonatal and adult fast IIa SMHCs), were generously provided by H. M. Blau of Stanford University; the isoform specificities of these mAbs have been well characterized (cf. references in Condon et al., 1990a). Immunocytochemistry with commercially available anti-neurofilament and anti-synaptophysin mAbs (Boehringer Mannheim, Indianapolis, IN) and anti-desmin antiserum (prepared against chicken gizzard desmin; Sigma, St. Louis, MO) was performed according to the manufacturer's recommendations. Antibody binding was visualized using horseradish peroxidase (HRP)-conjugated or fluorescein-conjugated $\mathrm{F}\left(\mathrm{ab}^{\prime}\right)_{2}$ fragment goat anti-mouse Ig antibodies (Cappel, West Chester, PA) at 1:25 dilution. Antibody specificity was determined by comparing sections labeled with a primary antibody (such as mAb 3G2) and an appropriate secondary antibody to adjacent sections reacted with secondary antibody only.

Labeling of AChRs was achieved by the addition of rhodamine-conjugated $\alpha$-bungarotoxin (rBTX; Molecular Probes, Eugene OR) to the secondary antibody solution or, alternatively, by a 5 min incubation with rBTX following secondary antibody incubation. In either case, a final dilution of 1:100 rBTX was used. On some slides, sections were double labeled with a mAb and the actin probe, rhodamine phalloidin (approximately $20 \mathrm{nM}$; Molecular Probes), following the methods used for rBTX.

Whole muscles. Labeling of whole muscles was performed in parallel using three types of preparations: fixed, permeabilized, or untreated. For fixation, freshly dissected muscles were immersed in $1 \%$ neutral buffered paraformaldehyde for $5 \mathrm{~min}$ at room temperature. For permeabilization, muscles were frozen for $30 \mathrm{~min}$ in $\mathrm{MeOH}$ chilled to $-20^{\circ} \mathrm{C}$. The muscles were processed for immunocytochemistry as above, using mAb 3G2 or mAb 35, an antibody directed against an extracellular epitope of the AChR (Tzartos et al., 1981; Developmental Studies Hybridoma Bank, Iowa City, IA). Visualization of $m A b 35$ was achieved using a fluorescein-conjugated goat anti-rat secondary antibody (Cappel). Nuclei were labeled by including propidium iodide $(0.04 \mu \mathrm{g} / \mathrm{ml}$; Sigma) in the secondary antibody solution.

\section{Muscle extractions.}

As a first step in attempting to identify the antigen for mAb 3G2, proteins were extracted from adult and neonatal rat muscle. To enrich for proteins concentrated at the neuromuscular junction of adult animals, the central region (roughly one-fifth) of each of several hemidiaphragms was dissected, weighed, and frozen. (Pilot experiments, in which diaphragms were stained for acetylcholinesterase, confirmed that the majority of neuromuscular junctions were contained in this region.) For neonatal material, frozen hindlimb musculature from several animals was pooled, weighed, and frozen. The dissected pieces of the adult hemidiaphragm or neonatal hindlimb muscle samples were homogenized and sequentially extracted in parallel at $0-4^{\circ} \mathrm{C}$. Low salt-, detergent-, and high ionic strength-soluble extracts were obtained following the methods of Burden (1982) with the following modifications: pellets were collected after centrifugation at $17,000 \times g$ for $10 \mathrm{~min}$, and the high ionic strength extract was collected after $1 \mathrm{hr}$ incubation. The insoluble residue remaining after extraction with high ionic strength buffer was washed with distilled $\mathrm{H}_{2} \mathrm{O}$, pelleted, and resuspended by homogenization in $6 \mathrm{~m}$ urea, $5 \mathrm{~mm}$ EDTA, $0.1 \% 2$-mercaptoethanol, 10 mm sodium phosphate, $\mathrm{pH} 7.5$ (Huiatt et al., 1980). The homogenate was mixed for $10 \mathrm{~min}$ and then centrifuged $(17,000 \times g$ for $10 \mathrm{~min})$. The urea extract was dialyzed against $10 \mathrm{~mm}$ Tris acetate, $5 \mathrm{~mm}$ 2-mercaptoethanol, pH 7. Extracts from each step, as well as aliquots of the final urea-insoluble pellets were mixed with SDS sample buffer and boiled for subsequent analysis by SDS-PAGE.

\section{SDS-PAGE and immunoblotting.}

SDS-PAGE was carried out in a discontinuous system employing $13 \%$ polyacrylamide in the separating gel (Laemmli, 1970). Gels were elecrophoretically transferred to nitrocellulose sheets using transblot buffer ( $25 \mathrm{~mm}$ Tris, $192 \mathrm{~mm}$ glycine, 20\% methanol) and a Genie blotter (Idea 


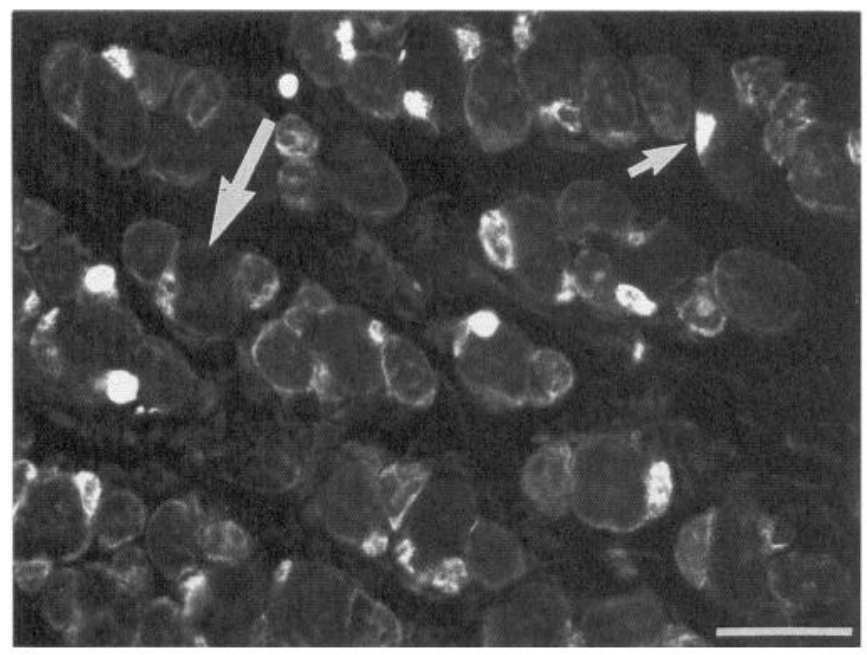

Figure 1. mAb $3 \mathrm{G} 2$ recognizes an antigen differentially distributed in neonatal muscle fibers. Cryostat cross sections of hindlimb musculature from a 1-d-old rat were reacted with $\mathrm{mAb} 3 \mathrm{G} 2$ and a fluorescein-conjugated second antibody. The smaller-diameter fibers (presumably fibers of the secondary generation) are brightly labeled (small arrow) whereas larger-diameter fibers are unlabeled or weakly labeled (large arrow). Scale bar, $25 \mu \mathrm{m}$.

Scientific, Corvallis OR) at $15 \mathrm{~V}(0.4-0.5 \mathrm{~A})$ for $45 \mathrm{~min}$. The blots were incubated for $30 \mathrm{~min}$ in $10 \mathrm{~mm}$ Tris, $150 \mathrm{~mm} \mathrm{NaCl}, 0.05 \%$ Tween-20, pH 8.0 (TBST) containing $1 \%$ BSA to block nonspecific protein binding. The nitrocellulose sheets were then incubated with mAb 3G2 or antidesmin $\mathrm{mAb}$ (porcine stomach as immunogen; Boehringer Mannheim) diluted to 1:500 in TBST for $1 \mathrm{hr}$ at room temperature, washed, incubated for $30 \mathrm{~min}$ with a 1:7500 dilution of alkaline phosphataseconjugated anti-mouse second antibody (Promega Protoblot kit, Madison, WI), washed, and finally developed in substrate solution for $5 \mathrm{~min}$. The apparent molecular masses of bands of interest were determined by comparing their mobilities to those of standard molecular mass markers (Sigma).

\section{Results}

\section{Isolation of $\mathrm{mAb} 3 G 2$}

With the goal of identifying fiber type-selective surface components on developing muscle fibers, we set out to generate monoclonal antibodies to rat muscle membrane. In an attempt to suppress the production of antibodies against epitopes common to adult and developing muscles, a tolerization/immunization regimen was followed (Hockfield, 1987, and personal communication). Briefly, newborn mice were repeatedly inoculated with an adult muscle membrane preparation. Several weeks later, these mice were immunized with a membrane preparation derived from denervated neonatal muscle, with the aim of enriching for neonatal-specific antigens whose expression might be suppressed by innervation. Lymphocytes isolated from these mice were fused with myeloma cells, and the resultant hybridomas were screened by indirect immunofluorescence on cryostat cross sections of newborn rat hindlimb.

mAb 3G2 was initially selected from such a screen because it labeled a subset of the fibers present in the newborn hindlimb with a pattern suggestive of a fiber type-selective antigen. In general, small-diameter muscle fibers were brightly labeled with mAb 3G2, whereas most larger fibers were unlabeled or weakly labeled (Fig. 1). However, it quickly became clear that mAb $3 \mathrm{G} 2$ labeling was not fiber type selective. While mAbs to neo- natal/fast IIa myosin and to slow myosin indicated that the majority of the mAb 3G2-positive small-diameter fibers were fast, there was no apparent correlation between the intensity of mAb 3G2 labeling of larger-diameter fibers and their myosin content. Moreover, fibers present in E15 hindlimb were immunopositive for $\mathrm{mAb} 3 \mathrm{G} 2$. Since these fibers become the larger-diameter fibers of the newborn hindlimb, the apparent differential labeling of small versus large fibers seen at birth is likely to be the result of differences in fiber maturity. Hence, all muscle fibers were generally immunoreactive for mAb $3 \mathrm{G} 2$ at the time of their generation. Interestingly, this general immunoreactivity was lost with development such that in the adult, mAb 3G2 labeling was spatially restricted to neuromuscular and myotendinous junctions (see below). Furthermore, immunoreactivity to mAb $3 \mathrm{G} 2$ was not detected in sections through other adult tissue including cardiac muscle, smooth muscle, and autonomic ganglia. Thus, it was this restricted pattern of immunoreactivity that ultimately prompted further study with $\mathrm{mAb}$ $3 \mathrm{G} 2$.

\section{$m A b 3 G 2$ recognizes an intracellular epitope subjacent to $A C h$ receptors at the adult neuromuscular junction}

Cross sections made through the center of an adult rat soleus muscle revealed the presence of mAb $3 \mathrm{G} 2$ immunoreactivity restricted to a few sites located along the perimeter of some of the muscle fibers (Fig. 2A). Immunoreactivity outside these sites was identical to that obtained by incubation of sections with secondary antibody alone. mAb 3G2-immunoreactive sites could be shown to be neuromuscular junctions by double labeling such sections with mAb $3 \mathrm{G} 2$ and with rBTX (a probe for ACh receptors), as the sites immunopositive for $\mathrm{mAb} 3 \mathrm{G} 2$ were also stained by rBTX (Fig. $2 A, B$ ). Examination of many such sections, including sections $2-3 \mu \mathrm{m}$ in thickness, showed that the two labels were not strictly coincident (Fig. 2C,D). Almost all the synaptic gutters stained with rBTX were associated with mAb 3G2 immunoreactivity. However, mAb 3G2 immunoreactivity generally extended slightly beyond the regions labeled by rBTX. Often, regions between two synaptic gutters were occupied by a protrusion from muscle surface (probably corresponding to the sarcoplasmic protrusions described in scanning electron micrographs; Desaki and Uehara, 1987) that was mAb 3 G2 positive but rBTX negative. Photographic double exposures of the fluorescein and rhodamine images indicated that the $\mathrm{mAb}$ immunoreactivity in the synaptic gutters lay deeper (relative to the muscle fiber surface) than the rBTX labeling, suggesting that the epitope for mAb $3 \mathrm{G} 2$ was internal to the muscle fiber (data not shown).

To confirm the intracellular localization of the epitope for mAb 3G2 as well as to obtain a more complete picture of its distribution at the junction, we attempted to label whole muscle fibers using $\mathrm{mAb} 3 \mathrm{G} 2$. Labeling was obtained in permeabilized (Fig. $3 A$ ) and in fixed muscle fibers, but not in ones that were untreated. In contrast, antibody labeling of AChRs was obtained in muscle fibers without prior permeabilization or fixation using mAb 35 (Tzartos et al., 1981), a mAb directed against an extracellular epitope of the $\alpha$-subunit of the receptor (data not shown). Thus, this extracellular epitope present at the neuromuscular junction is accessible in untreated muscle, suggesting that the lack of mAb $3 \mathrm{G} 2$ labeling in untreated muscle is a consequence of an intracellular location for its epitope rather than an extracellular location with restricted access.

Muscle fibers viewed after permeabilization and double la- 

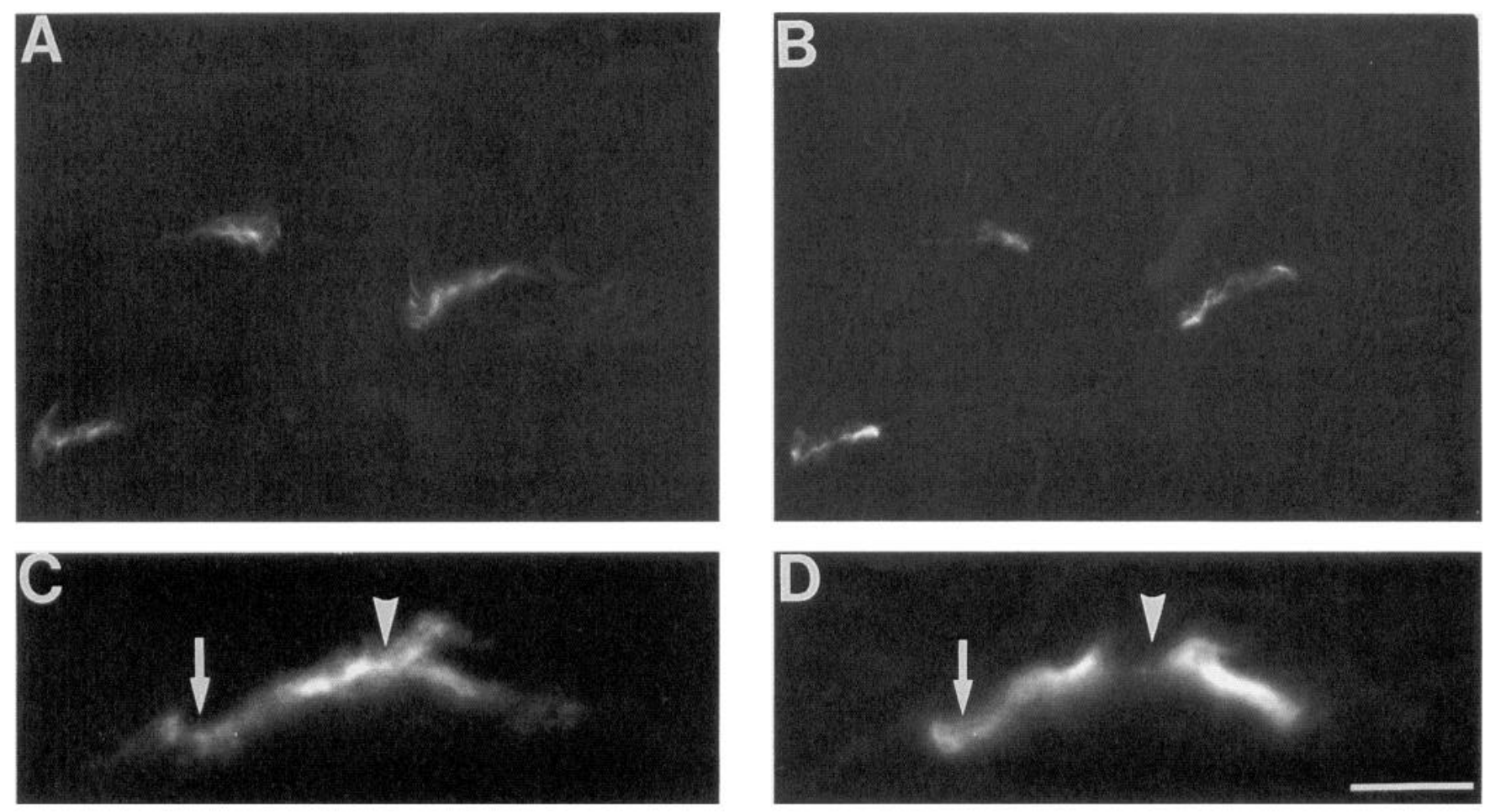

Figure 2. mAb 3G2 labels the neuromuscular junction in adult rat skeletal muscle. A $10 \mu \mathrm{m}(A$ and $B)$ and a $2 \mu \mathrm{m}(C$ and $D)$ cross section of the soleus muscle were double labeled with mAb $3 \mathrm{G} 2$ followed by a fluorescein-conjugated second antibody $(A$ and $C)$ and with $\mathrm{rBTX}$, an AChR receptor ligand $(B$ and $D$ ). Every junction identified by rBTX is labeled by mAb $3 \mathrm{G} 2$. Extrajunctional labeling with mAb $3 \mathrm{G} 2$ is not above the background obtained by application of secondary antibody alone. Examination of thinner sections at higher magnification $(B$ and $D)$ shows that the labels are not identical. mAb 3G2 labeled AChR-rich synaptic gutters (arrows) but also labeled areas between gutters devoid of AChRs (arrowheads). Some bright-field illumination was added to $B$ and $D$ to show the outlines of individual muscle fibers. Scale bar, $25 \mu \mathrm{m}$.

beling with $\mathrm{mAb} 3 \mathrm{G} 2$ and $\mathrm{rBTX}$ confirmed and extended the picture of junctional labeling obtained from cross sections. In junctions observed en face, the immunoreactivity to mAb 3G2 gave an essentially complementary image to that obtained with rBTX (Fig. 3; also see Fig. 4C,D). mAb 3G2 immunoreactivity was prominent at the edges of each of the synaptic gutters, outlining the pattern obtained with rBTX. This feature of the labeling may be explained by the superposition of immunoreactivity associated with the sides of each gutter (see Fig. $2 \mathrm{C}$ ) when viewed from above. mAb 3G2 immunoreactivity also filled areas betweeen some of the synaptic gutters (Fig. 3C) corresponding to similar areas seen in cross sections (Fig. 2C,D). Lastly, mAb 3G2 labeled striations beneath the neuromuscular junction (Fig. 3C). These striations had the periodicity of sarcomeres (ca. $2.5 \mu \mathrm{m}$ ) but were confined to the endplate region, extending approximately $50 \mu \mathrm{m}$ or less along the length and 10 $\mu \mathrm{m}$ or less across the width of the fiber. Permeabilized fibers viewed from the side (Fig. $4 A$ ) indicated that the mAb 3G2 immunoreactivity found underneath the synaptic gutters was coextensive with the labeled striations. In addition, oval-shaped structures, unlabeled by mAb $3 \mathrm{G} 2$, appeared to be surrounded by $\mathrm{mAb} 3 \mathrm{G} 2$ immunoreactivity (Fig. 4C). These structures were shown to be sole plate nuclei by the application of the nucleic acid dye propidium iodide (data not shown).

Viewed through phase contrast optics, the mAb 3G2-positive striations corresponded to phase-dense lines found within the center of phase-bright I-bands (data not shown), suggesting that $\mathrm{mAb} 3 \mathrm{G} 2$ labeling was localized at or near the Z-disk of the sarcomere. Further support for this notion was obtained by double labeling longitudinal sections of adult soleus muscle with $\mathrm{mAb} 3 \mathrm{G} 2$ and with a rabbit polyclonal antibody directed against desmin. mAb 3G2 and the anti-desmin antibody labeled identical sets of striations within the perijunctional region (Fig. 5). However, the anti-desmin antibody labeled the Z-disks throughout each fiber, whereas $\mathrm{mAb} 3 \mathrm{G} 2$ did not.

Although the difference in the extent of Z-disk-associated labeling argues that the antigen for mAb $3 \mathrm{G} 2$ is distinct from desmin, mAb 3G2 labeling of the junction itself bears a striking similarity to the junctional labeling obtained with anti-desmin mAbs [compare Fig. $3 C$ and $4 C$ with Fig. 5 in Sealock et al. (1989)]. Thus, we conducted experiments to further examine this issue. We attempted to mask desmin immunoreactivity using rabbit polyclonal anti-desmin antiserum. Slides containing cross sections of adult rat soleus muscle were incubated with anti-desmin at a concentration of fivefold greater than that required for optimal indirect immunofluorescence (as determined by the manufacturer and our own observations), rinsed, and then processed for immunocytochemistry with mAb $3 \mathrm{G} 2$ in the usual fashion. Preincubation with polyclonal desmin antiserum had no effect on the intensity or localization of mAb $3 \mathrm{G} 2 \mathrm{im}-$ munoreactivity (data not shown). While these results do not rule out the possibility that mAb $3 \mathrm{G} 2$ binds to desmin, they are consistent with the results of immunoblotting experiments reported below.

Thus, mAb 3G2 immunoreactivity at the neuromuscular junction was found lining the synaptic gutters, filling sarcoplasmic protrusions between gutters, surrounding sole plate nuclei, and associating with Z-disks in the vicinity of the junction. 

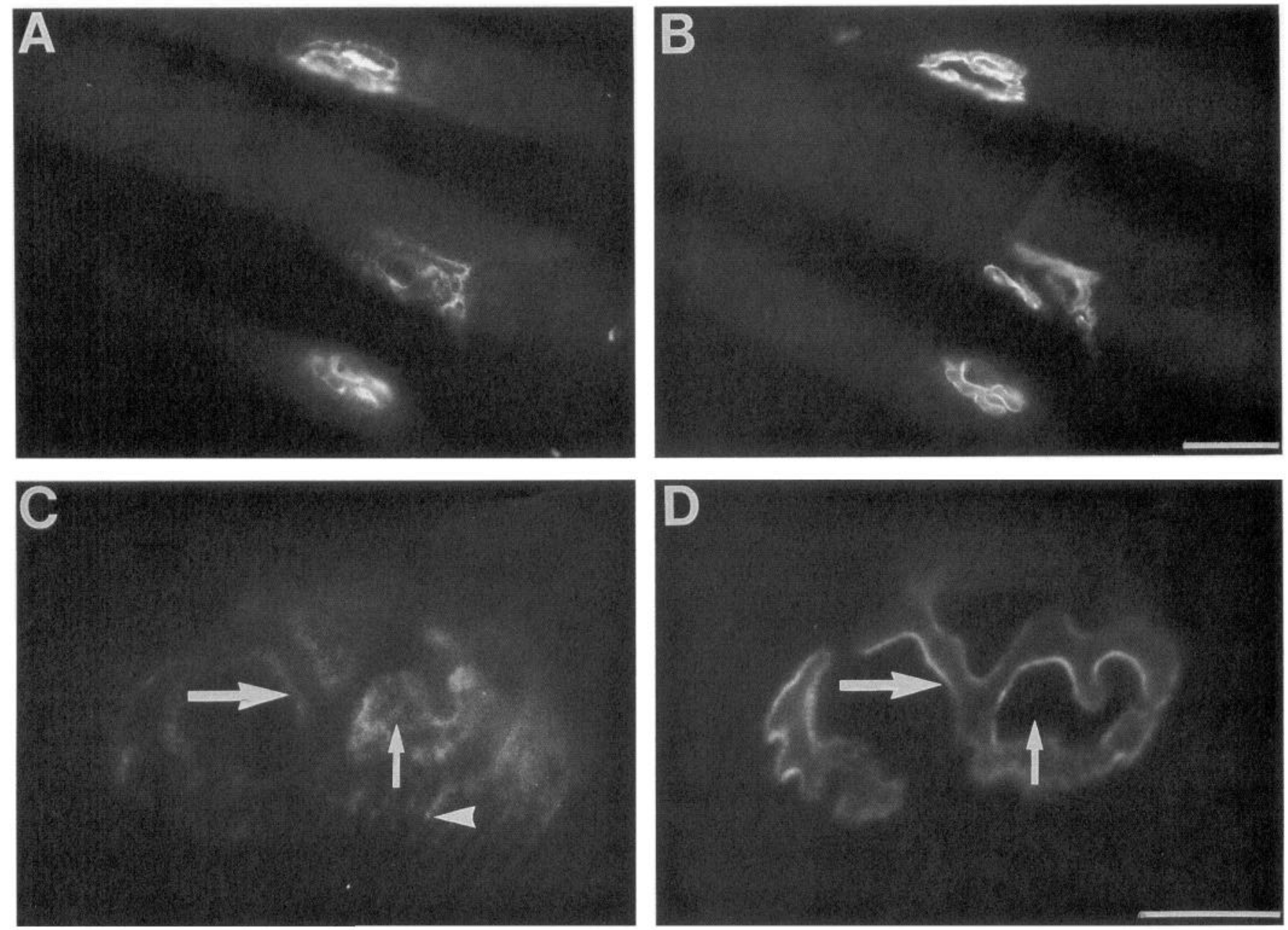

Figure 3. mAb $3 \mathrm{G} 2$ reacts with an intracellular epitope at the adult neuromuscular junction. An adult flexor digitorum tibialis muscle was permeabilized and double labeled with mAb $3 \mathrm{G} 2$ followed by a fluorescein-conjugated second antibody $(A$ and $C)$ and with rBTX $(B$ and $D)$. At low magnification $(A$ and $B)$, mAb $3 \mathrm{G} 2$ immunoreactivity is localized to the neuromuscular junction of each fiber and is not found at extrajunctional sites. At higher magnification ( $C$ and $D$ ), details of the labeling can be seen. mAb 3G2 labeling follows the contours of the synaptic gutters (large arrows in $C$ and $D$ ), and in many cases fills the spaces between gutters (small arrows in $C$ and $D$ ). In general, the mAb $3 \mathrm{G} 2$ labeling presents a negative image of that obtained with rBTX. Additionally, mAb 3G2 labels striations in the perijunctional region of the fiber (arrowhead in $C$ ). Scale bars: $25 \mu \mathrm{m}$ for $A$ and $B ; 10 \mathrm{~mm}$ for $C$ and $D$.

\section{mAb $3 G 2$ labels a component of the adult myotendinous junction}

In addition to labeling the neuromuscular junction, $\mathrm{mAb} 3 \mathrm{G} 2$ recognized a component of the myotendinous junction. Here again, mAb 3G2 labeling was prominent in striations with a periodicity characteristic of sarcomeres (Fig. 6). Immunoreactivity to $\mathrm{mAb} 3 \mathrm{G} 2$ was not detectable at distances of $25 \mu \mathrm{m}$ or more from a tendon.

\section{Biochemical identification of the $3 G 2$ antigen}

In an attempt to identify the protein bearing the $3 \mathrm{G} 2$ epitope, the antibody was used in immunoblots. No immunoreactive band could be detected in samples of newborn muscle or adult muscle pulverized under liquid nitrogen and taken up into SDS sample buffer. However, we were successful in identifying an immunoreactive band in certain extracts of newborn muscle. These extracts were prepared by sequentially homogenizing tissue in a low ionic strength buffer, a low ionic strength buffer containing Triton X-100, a high ionic strength buffer, and urea. The material insoluble in urea buffer was also collected. These fractions were resolved using SDS-PAGE, blotted to nitrocellulose, and probed with $\mathrm{mAb} 3 \mathrm{G} 2$ using an alkaline phosphatase detection system. A single $41 \mathrm{kDa}$ band was detected in each of two fractions: the fraction containing urea-insoluble material (Fig. $7 C$ ) and the fraction prepared by extraction in high salt (data not shown). In each case, this band was clearly a minor component of the total protein in the fraction, as no corresponding band was visible in identical protein samples subjected to coelectrophoresis and stained with Coomassie blue (cf. Fig. 7B). Thus, $\mathrm{mAb}$ recognizes a $41 \mathrm{kDa}$ protein that is relatively insoluble.

We attempted to immunoblot identical extracts of adult muscle, but no bands were detectable with $\mathrm{mAb} 3 \mathrm{G} 2$ on these blots. We believe our failure is explained by the quantity of the antigen present in adult muscle. On the basis of immunocytochemistry, adult muscle contains lower levels of immunoreactivity than does newborn muscle, and even in newborn muscle, the $41 \mathrm{kDa}$ protein is only a minor component of each extract in which it can be detected.

Because of the observed similarity in the junctional labeling achieved with mAb $3 \mathrm{G} 2$ and that reported for anti-desmin an- 

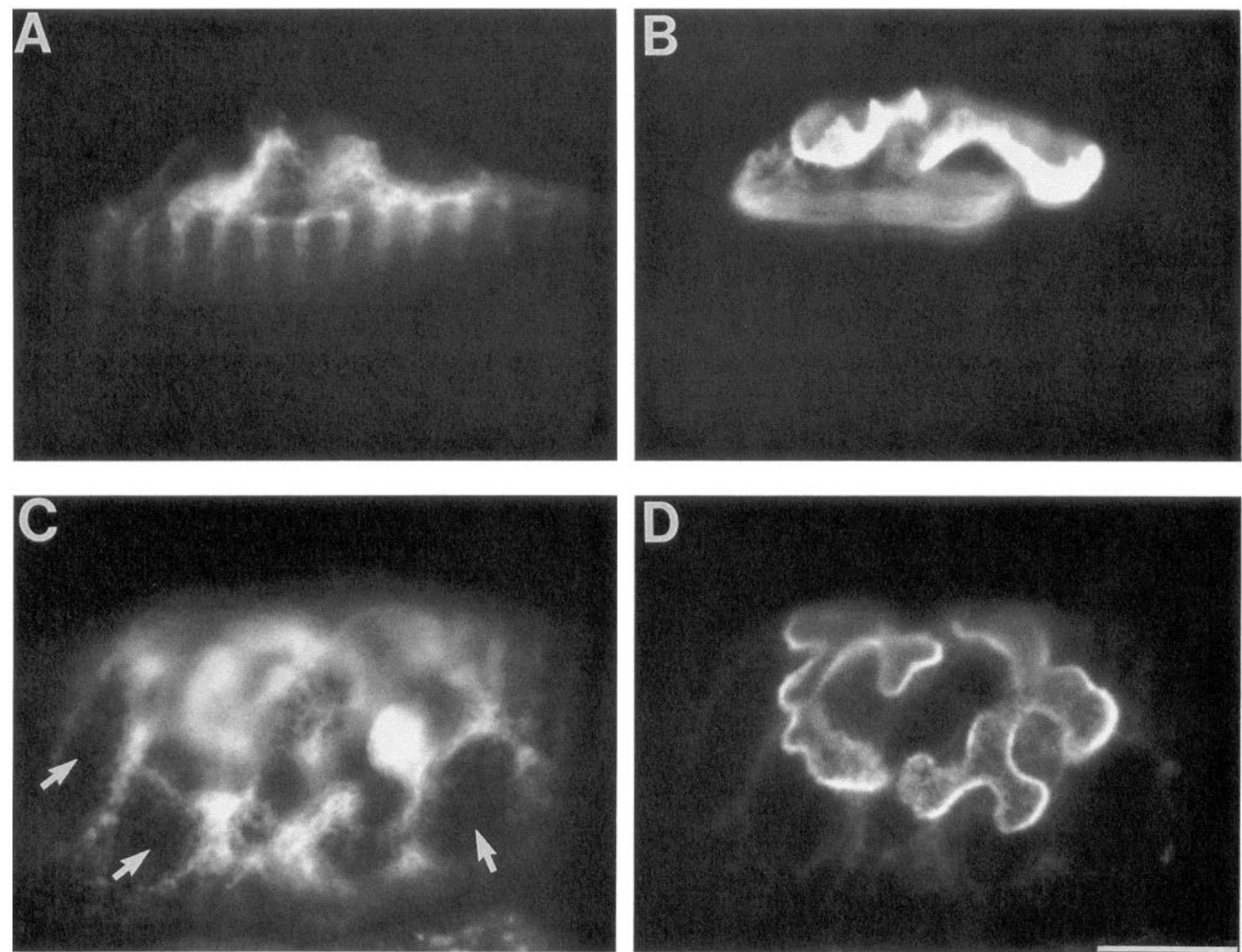

Figure 4. mAb 3G2 immunoreactivity extends beneath the junction in striations and surrounds sole plate nuclei. Permeabilized fibers from the flexor digitorum tibialis were double labeled with mAb 3G2 followed by a fluorescein-conjugated second antibody $(A$ and $C)$ and with rBTX $(B$ and $D$ ). Viewed from the side $(A$ and $B)$, mAb 3G2 labeling in the junction appears continuous with the labeling of intracellular striations. In another fiber viewed en face $(C$ and $D)$, the labeling pattern is interrupted by holes (arrows) shown in separate experiments to be sole plate nuclei. Scale bar, $10 \mu \mathrm{m}$.
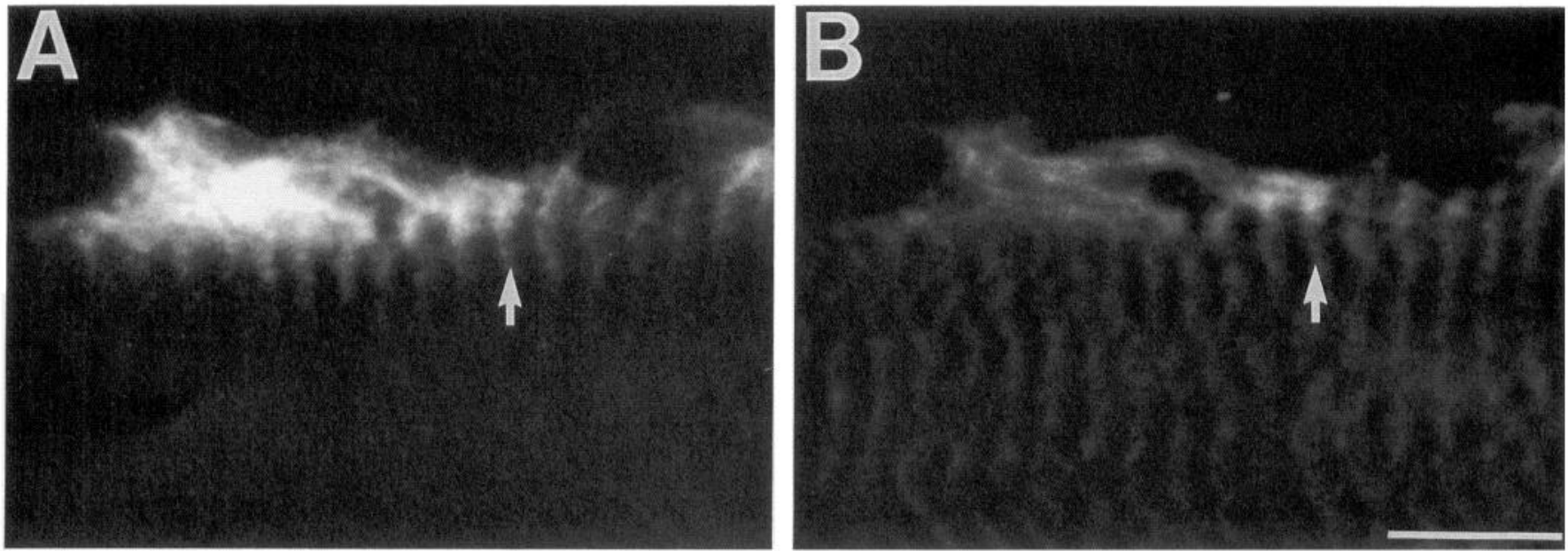

Figure 5. The striations labeled with mAb 3G2 lie at or near the Z-disk. A longitudinal section of an adult soleus muscle was labeled with the following reagents: $\mathrm{mAb} 3 \mathrm{G} 2$ (followed by a fluorescein-conjugated second antibody to mouse IgG), a rabbit polyclonal anti-desmin antibody (followed by a rhodamine-conjugated second antibody to rabbit IgG), and rBTX. The neuromuscular junction and the striations below the junction are labeled by mAb $3 G 2(A)$. The junction and the Z-disks extending throughout the fiber are labeled by the anti-desmin antibody $(B)$. The labeling of the striations in $A$ is coincident with the labeling of the Z-disks in $B$. One such coincidence is shown by the arrows. Scale bar, $10 \mu \mathrm{m}$. 


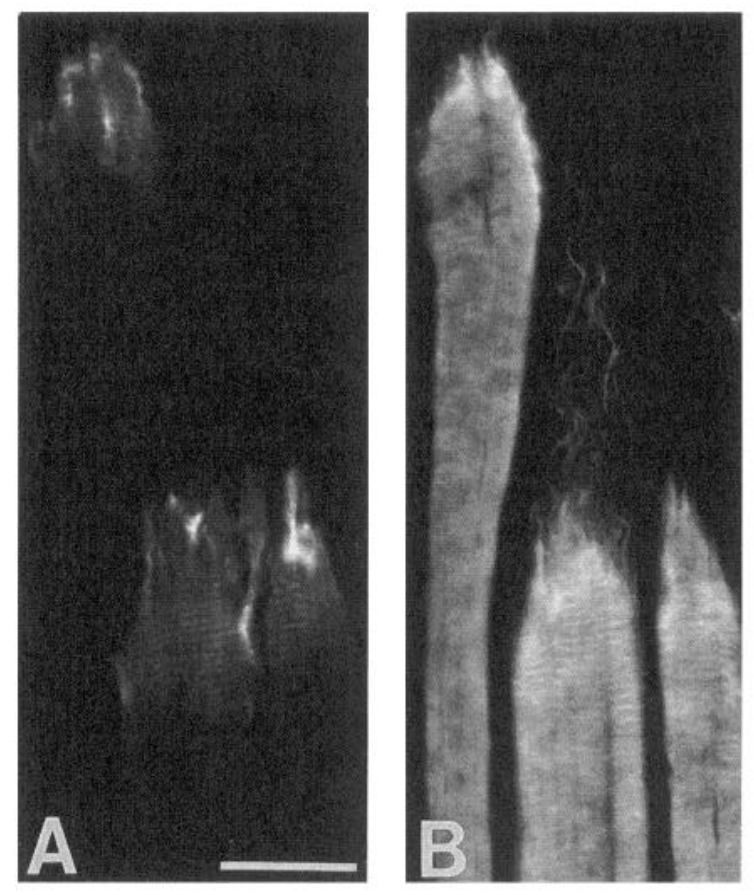

Figure 6. mAb 3G2 labels myotendinous junctions in adult muscles. Longitudinal section of the myotendinous region of an adult rat soleus muscle double labeled with mAb $3 \mathrm{G} 2$ followed by a fluorescein-conjugated second antibody $(A)$ and with rhodamine-phalloidin $(B)$. Phalloidin, a stain for actin, reveals the myofibrils within the fibers and indicates their sarcomeric arrangement. At the ends of the fibers, $\mathrm{mAb}$ 3G2 labels striations with a sarcomeric periodicity. Scale bar, $25 \mathrm{~mm}$.

tibodies, we sought to determine whether mAb $3 G 2$ reacted with rat desmin on immunoblots. Adult muscles were pulverized under liquid nitrogen, boiled immediately in SDS sample buffer, and immunoblotted with $\mathrm{mAb} 3 \mathrm{G} 2$ or with a commercial anti-desmin $\mathrm{mAb}$. mAb $3 \mathrm{G} 2$ recognized no band(s) in this preparation (Fig. 7D) whereas the anti-desmin $\mathrm{mAb}$ reacted with an approximately $50 \mathrm{kDa}$ band, consistent with the known molecular mass of desmin (Fig. $7 E$ ). Thus, the $41 \mathrm{kDa}$ band recognized by $\mathrm{mAb} 3 \mathrm{G} 2$ is clearly not desmin nor does this antibody react with rat desmin.

\section{The $3 G 2$ antigen becomes localized to the neuromuscular junction during early postnatal development}

As noted above, mAb $3 \mathrm{G} 2$ immunoreactivity was prominent in muscle fibers during early development whereas in the adult it was localized to neuromuscular and myotendinous junctions. Thus, we sought to determine whether mAb 3G2 immunoreactivity was associated with these or other structures within nascent muscle fibers. Newborn rat hindlimb cross sections double labeled with mAb $3 \mathrm{G} 2$ and the actin probe rhodamine phalloidin revealed largely complementary labeling patterns, indicating that mAb $3 \mathrm{G} 2$ immunoreactivity was located in the sarcoplasm between, but not within, myofibrils (Fig. 8A,B). Other sections, double labeled with mAb $3 \mathrm{G} 2$ and the nucleic acid stain propidium iodide (data not shown), demonstrated that large, central mAb 3G2-immunonegative regions corresponded to the location of myonuclei (arrow in Fig. 8A). Longitudinal sections revealed several distributions of antibody labeling including reticular networks (Fig. $8 \mathrm{C}$ ), longitudinally arrayed filaments (Fig. $8 D$ ), and transverse bands with a periodicity (ca. $2.5 \mu \mathrm{m}$ ) characteristic of sarcomeres (Fig. $8 E$ ). In addition, some

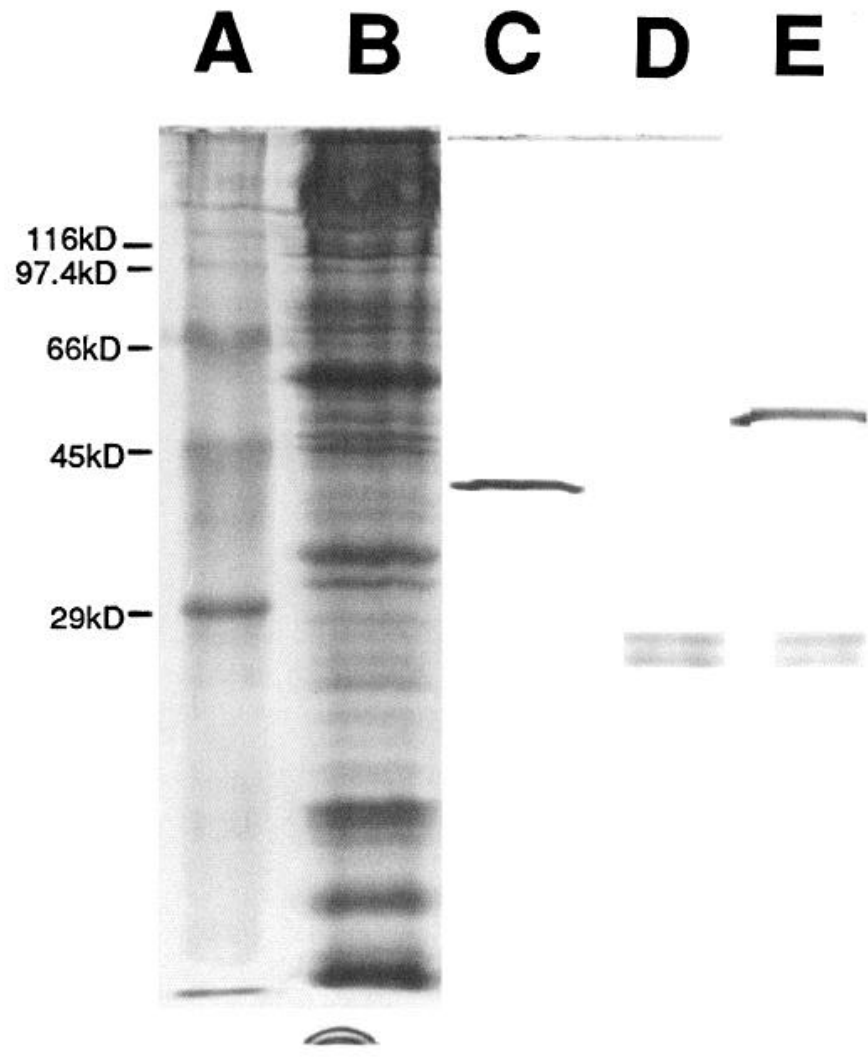

Figure 7. mAb $3 \mathrm{G} 2$ recognizes a $41 \mathrm{kDa}$ protein on immunoblots of neonatal muscle extracts but does not recognize desmin. Electrophoresis of standards and muscle extracts was performed on $13 \%$ polyacrylamide gels in the presence of SDS. The following samples were applied to different lanes of the same gel: lane $A$, molecular mass markers; lanes $B$ and $C$, the insoluble residue remaining following sequential extraction of neonatal rat muscle with low-salt, detergent-containing low-salt, highsalt, and urea buffers; lanes $D$ and $E$, adult rat muscle pulverized under liquid $\mathrm{N}_{2}$. Following electrophoresis, the portion of the gel containing lanes $A$ and $B$ was stained for protein using Coomassie blue. The molecular masses of the markers are indicated to the left of lane A. Lanes $C, D$, and $E$ were blotted to nitrocellulose and reacted with $\mathrm{mAb} 3 \mathrm{G} 2$ (lanes $C$ and $D$ ) or with a commercial monoclonal antibody to desmin (lane $E$ ). Antibody binding for $C, D$, and $E$ was visualized using a commercial alkaline phosphatase kit. mAb $3 \mathrm{G} 2$ recognizes a single protein band with an apparent molecular mass of $41 \mathrm{kDa}$ in the neonatal muscle extract $(C)$ but no protein in the adult muscle extract $(D)$. The anti-desmin antibody recognizes an approximately $50 \mathrm{kDa}$ band in the adult muscle extract $(E)$. The doublets below $29 \mathrm{kDa}(D$ and $E)$ were also seen in controls in which primary antibody was omitted and therefore reflect nonspecific reactivity of the secondary antibody.

small-diameter fibers contained mAb 3G2 labeling throughout their entire length (Fig. $8 \mathrm{C}$ ). Thus, various patterns of $\mathrm{mAb} 3 \mathrm{G} 2$ labeling were seen within the sarcoplasmic regions of developing myotubes, but this labeling was not consistently associated with identifiable cellular structures with one prominent exception, namely, the tendon. mAb 3G2 immunoreactivity was found within the sarcoplasm of each fiber at its myotendinous junction (Fig. 9).

We next sought to determine at what time in development mAb 3G2 immunoreactivity became concentrated at the neuromuscular junction. For this purpose, cryostat cross sections of muscles at various stages of development were prepared and double labeled with $\mathrm{mAb} 3 \mathrm{G} 2$ and $\mathrm{rBTX}$.

At E17, rBTX labeling of AChRs could be detected, but these 
regions did not contain mAb 3G2 immunoreactivity above background levels (data not shown). mAb 3G2 labeling was present; it was particularly prominent at myotendinous junctions, as expected. On the day of birth, neuromuscular junctions were more intensely labeled with rBTX than at E17, but mAb 3G2 labeling was still not detectable at these junctions (Fig. $10 A, B)$. Myotendinous junctions appeared labeled with mAb $3 \mathrm{G} 2$, as did the profiles of many small-diameter fibers (see above).

Localization of mAb $3 \mathrm{G} 2$ immunoreactivity to the neuromuscular junction was first observed at P4 when a few of the junctions identified by rBTX labeling were also labeled by $\mathrm{mAb}$ 3G2 (Fig. 10C,D). The colocalization of the two labels increased with postnatal development. By P7, almost every rBTX-positive region was also labeled by $\mathrm{mAb} 3 \mathrm{G} 2$ and $\mathrm{mAb} 3 \mathrm{G} 2$ labeling was absent from regions other than neuromuscular and myotendinous junctions (Fig. $10 E, F$ ). Thus, in the muscles of the hindlimb, mAb 3G2 immunoreactivity begins to be concentrated at neuromuscular junctions during the first postnatal week, several days after localized high concentrations of AChRs were detected at these synapses.

\section{Expression of the $3 G 2$ antigen at the neuromuscular junction is innervation dependent}

The distributions of several of the proteins concentrated at the neuromuscular junction have been shown to be regulated by innervation (Froehner et al., 1981; Burden, 1982). In most cases, the response to denervation is similar to that seen for the $\mathrm{AChR}$, namely, an increase in extrajunctional concentration (while levels at the junction remain high), followed by the loss of extrajunctional expression upon reinnervation. We sought to determine whether the antigen recognized by mAb $3 \mathrm{G} 2$ was similarly regulated.

To examine potential changes in the distribution of $\mathrm{mAb} 3 \mathrm{G} 2$ immunoreactivity following denervation, we denervated the soleus muscles of several adult rats by unilateral resection of the tibial nerve. Six days after denervation, rBTX staining was observed in the soleus as expected, since AChRs are known to persist at high density at denervated endplates (Frank et al., 1976). Labeling with mAb $3 G 2$ was absent at most rBTX-labeled junctions and dramatically reduced at all others (Fig. 11). There was no change in the labeling of the sarcolemma outside the neuromuscular junction.

Because the maintenance of a junctional protein at denervated synapses is often used as an argument for its localization to muscle rather than nerve (see, e.g., Froehner et al., 1981), the absence of mAb $3 \mathrm{G} 2$ immunoreactivity following denervation might be interpreted as evidence that the antigen is localized to

Figure 8. Several patterns of $\mathrm{mAb} 3 \mathrm{G} 2$ immunoreactivity are seen in newborn rat fibers. A cross section of a myotube viewed at high magnification after double labeling with $\mathrm{mAb} 3 \mathrm{G} 2(A)$ and rhodaminephalloidin $(B)$ reveals that the antibody labeling lies in the spaces between myofibrils (identified by phalloidin staining; arrowhead in $A$ and $B$ ) and is absent from the nucleus located in the center of the myotube (arrow in $A$ ). $C-E$, Longitudinal sections of newborn soleus labeled with $\mathrm{mAb} 3 \mathrm{G} 2$ and a fluorescein-conjugated second antibody. Some small muscle fibers contain reticular immunoreactivity along their entire length (C). A small-diameter secondary myotube (small arrow) is apposed to the surface of a larger, unstained fiber (large arrow). Other fibers have patches of immunoreactivity in which longitudinal filaments $(D)$ or transverse bands with a sarcomeric periodicity $(E)$ are seen. In $E$, mAb 3G2 immunoreactivity is excluded from a nucleus (labeled $n$ ). Scale bar, $10 \mu \mathrm{m}$.
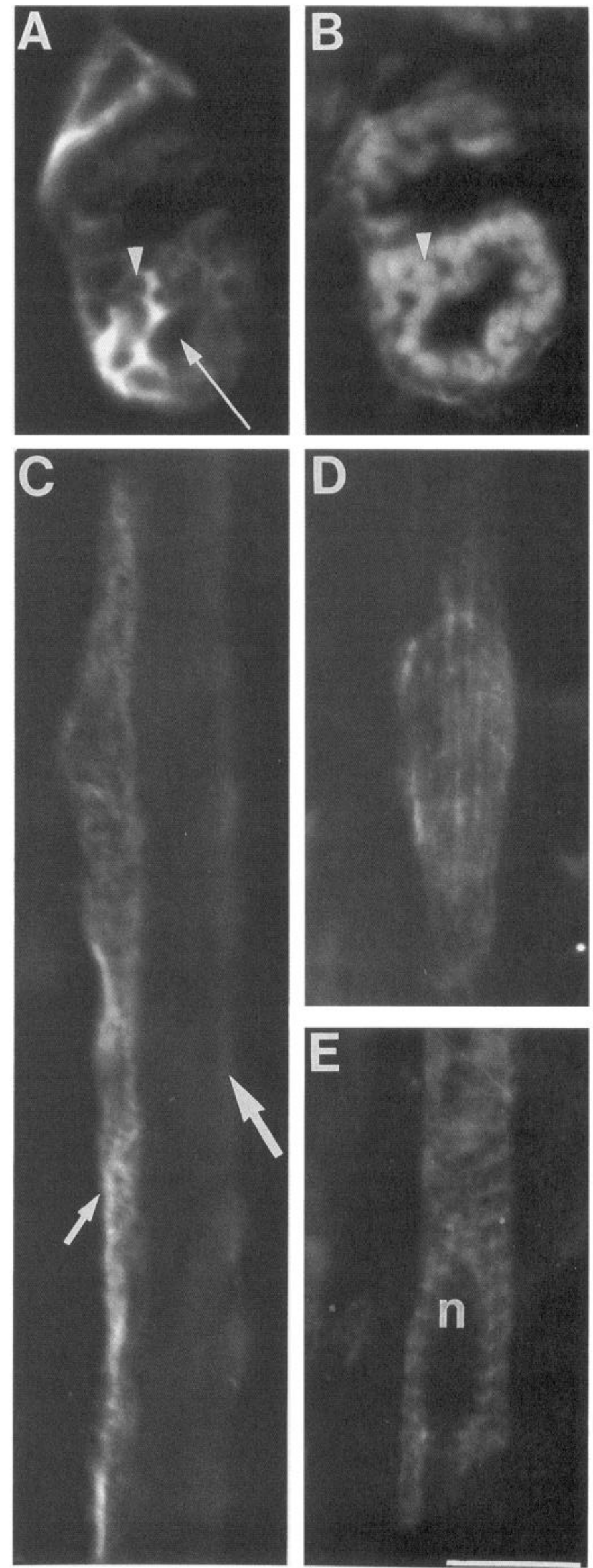

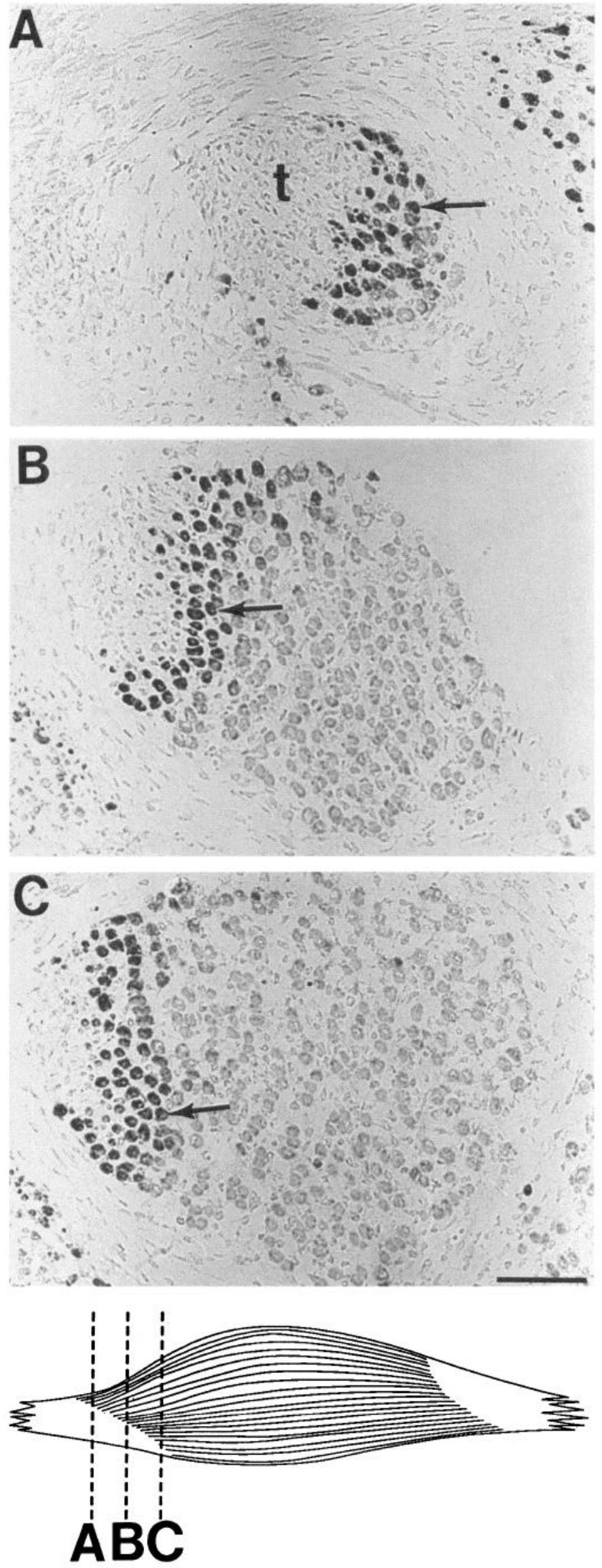

the motor nerve terminals. The present results, however, are inconsistent with such an explanation. The loss of $\mathrm{mAb} 3 \mathrm{G} 2$ immunoreactivity was effected over the course of several days; $4 \mathrm{~d}$ following denervation, mAb 3G2 immunoreactivity was still detectable at junctions (data not shown). In contrast, nerve terminal degeneration has been shown to be largely complete $24 \mathrm{hr}$ following denervation (Miledi and Slater, 1970). Thus, the observed changes in mAb 3G2 immunoreactivity are presumed to be due to a loss of the antigen from the muscle fiber and indicate that innervation is required for its maintenance at the neuromuscular junction.

To determine whether innervation was similarly required for the initial localization of mAb 3G2 immunoreactivity at developing synapses, soleus muscles were denervated in 1-d-old pups, before synaptic localization had occurred. Four and eight days later, when localization was observed in control muscles, $\mathrm{mAb} 3 \mathrm{G} 2$ immunoreactivity was not detected at end plates in the denervated muscles (data not shown). This result argues that innervation is not only required to maintain expression of the $41 \mathrm{kDa}$ protein at neuromuscular junctions, but also to bring about its initial localization to these sites.

We also sought to determine the distribution of the mAb $3 \mathrm{G} 2$ antigen upon reinnervation. Desiring rapid reinnervation, we denervated adult soleus muscles by crush (rather than resection) of the tibial nerve in a set of littermates. The status of reinnervation was evaluated for one muscle at each selected time point by dissecting the nerve and muscle, connecting it to an isometric tension transducer, and comparing the tension produced by stimulation of the nerve proximal to the crush site to that produced by stimulation of the muscle directly. Following this measurement, the muscle was sectioned for immunocytochemical analysis.

Six days after nerve crush, reinnervation had not yet begun, and $\mathrm{mAb} 3 \mathrm{G} 2$ labeling was absent from $\mathrm{rBTX}$-labeled junctions, as expected from the results of the resection experiments reported above. Several days later, when approximately $80 \%$ of the fibers had become reinnervated, considerable mAb 3G2 immunoreactivity was detectable. At rBTX-labeled junctions, the intensity of $\mathrm{mAb} 3 \mathrm{G} 2$ labeling varied greatly; some junctions were heavily labeled, some were faintly labeled, and still others were unlabeled. In addition, each section contained some fiber profiles in which the entire sarcolemma and selected sarcoplasmic regions were mAb 3G2 immunopositive (data not shown), reminiscent of $\mathrm{mAb} 3 \mathrm{G} 2$ labeling of neonatal fibers. Such fiber profiles contained no corresponding rBTX labeling. In muscles that were $90 \%$ and $97 \%$ reinnervated (13 and $16 \mathrm{~d}$ following nerve crush, respectively), fiber profiles with extrajunctional $\mathrm{mAb}$ 3G2 immunoreactivity were increasingly prominent (Fig. 12). By $34 \mathrm{~d}$ following denervation, reinnervation was $100 \%$ complete. At this time, only a few fibers contained mAb 3G2 labeling of the extrajunctional sarcolemma and immunoreactivity at

Figure 9. Myotendinous junctions in developing muscles are labeled by $\mathrm{mAb} 3 \mathrm{G} 2$. Serial cross sections through an E17 extensor digitorum longus muscle were labeled with $\mathrm{mAb} 3 \mathrm{G} 2$ and an HRP-conjugated second antibody. HRP reaction product is visible in the sarcoplasm of fibers (arrows) where they join the muscle tendon (labeled $t$ in $A$ ). The diagram below the photographs illustrates the tendon arrangement in this muscle and how cross sections at different levels near the tendon contain fibers that are both adjacent to and removed from their myotendinous junctions. Scale bar, $50 \mu \mathrm{m}$. 

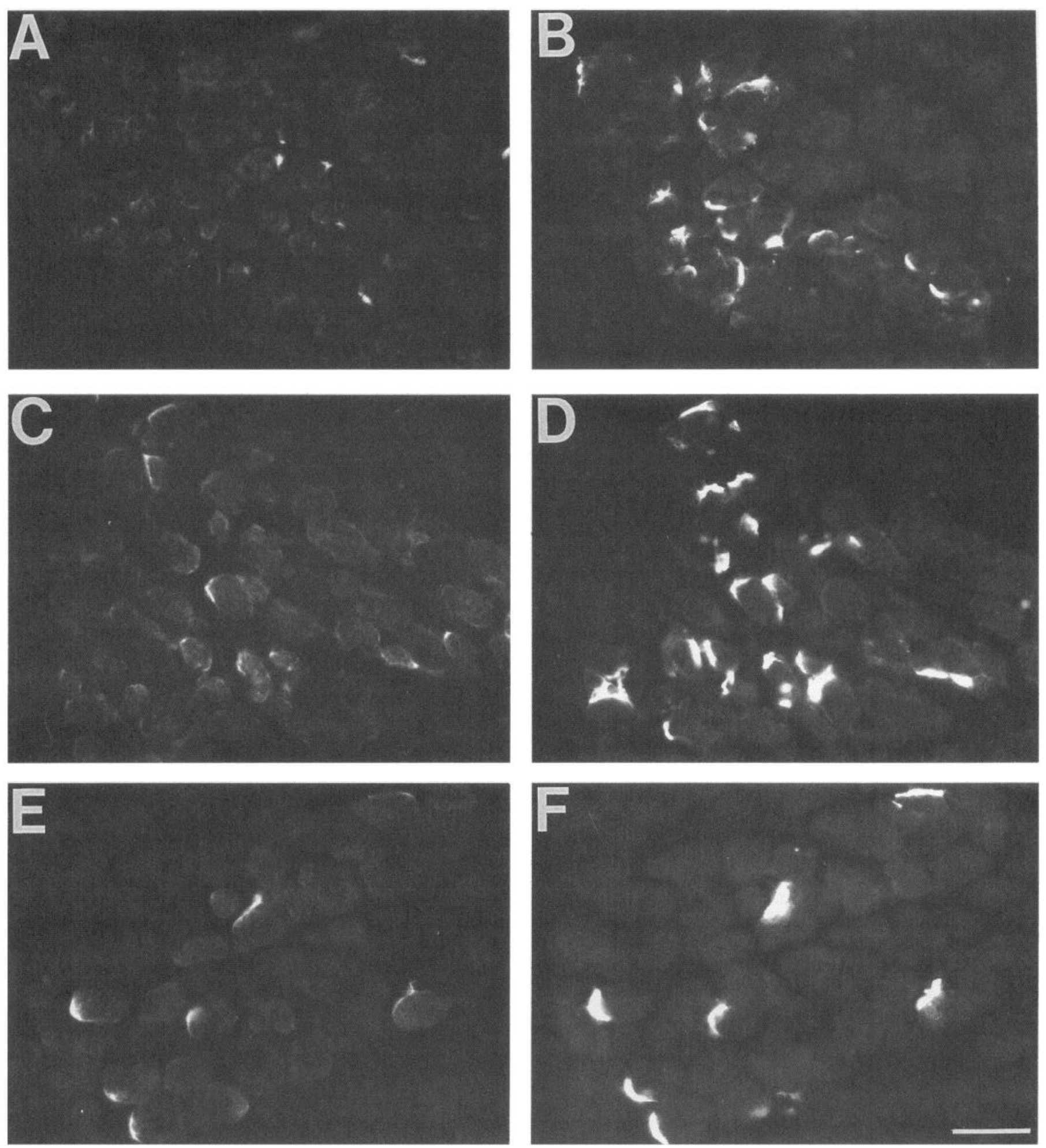

Figure 10. Immunoreactivity for mAb $3 \mathrm{G} 2$ becomes localized to the neuromuscular junction late in the first postnatal week of development. Cross sections of embryonic and postnatal rat hindlimb musculature were double labeled with mAb 3G2 followed by a fluorescein-conjugated second antibody $(A, C, E)$ and with $\operatorname{rBTX}(B, D, F)$. At E20 $(A$ and $B)$, there is discrete labeling of AChRs present at neuromuscular junctions but no labeling with mAb $3 \mathrm{G} 2$ at these sites. By P4 $(C$ and $D)$, some fibers begin to show localized expression of the $3 \mathrm{G} 2$ antigen at sites of staining for AChRs. By P7 $(E$ and $F)$, there is considerable colocalization of the labeling with mAb 3G2 and rBTX. Scale bar, $25 \mu \mathrm{m}$.

rBTX-labeled junctions appeared indistinguishable from controls. Thus, following reinnervation, mAb $3 \mathrm{G} 2$ immunoreactivity reappears extrajunctionally and gradually becomes localized to neuromuscular junctions.
Finally, we attempted to determine whether the expression of the mAb 3G2 antigen at the myotendinous junction was also innervation dependent. For this purpose, injections of the presynaptic neurotoxin $\beta$-bungarotoxin were made into rat fetuses 

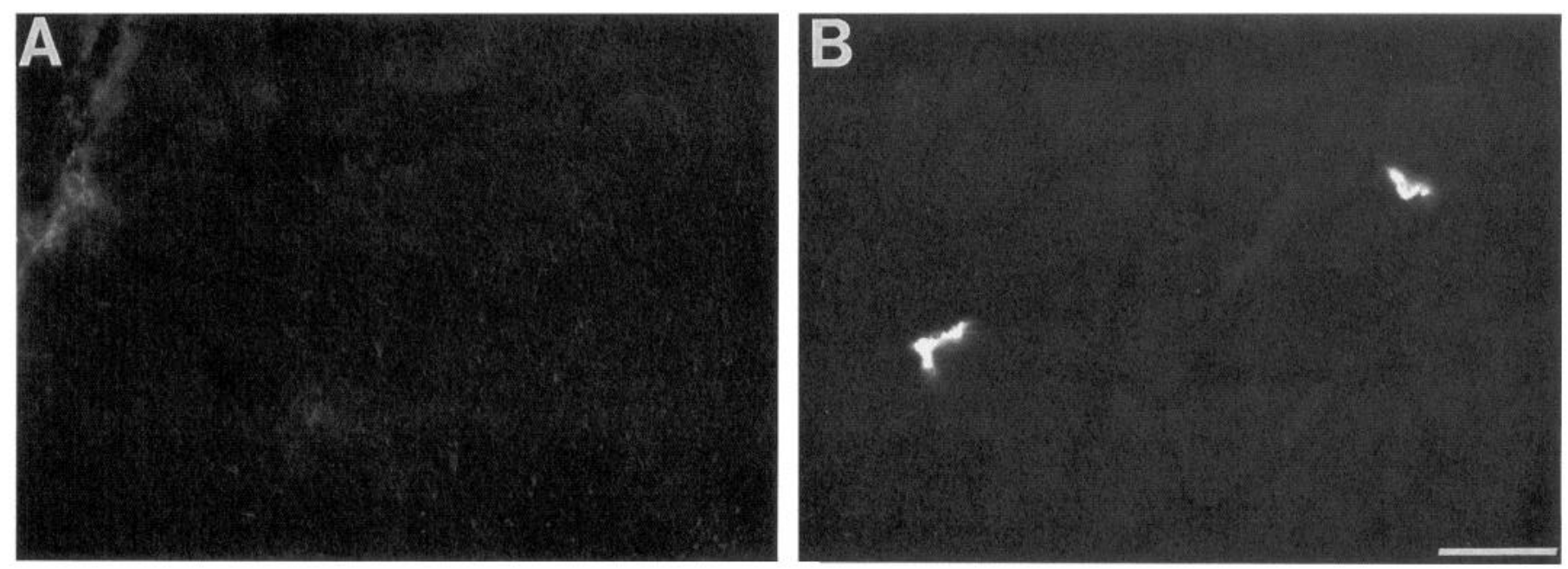

Figure 11. Immunoreactivity for mAb $3 \mathrm{G} 2$ at neuromuscular junctions is lost following denervation. A cross section of an adult soleus muscle made $6 \mathrm{~d}$ following denervation was double labeled with mAb 3G2 followed by a fluorescein second antibody $(A)$ and with rBTX $(B)$. Immunoreactivity is not detectable at either rBTX-labeled junction seen here. The fluorescein-labeled region (upper left in $A$ ) is due to nonspecific reactivity of the second antibody (data not shown). Scale bar, $25 \mu \mathrm{m}$.

on E14. Such a treatment has been shown to render the developing hindlimbs aneural (Condon et al., 1990b). Muscles from these animals were examined on E20. The status of hindlimb innervation was assessed by comparing hindlimb cross sections of treated and control animals processed for anti-neurofilament and anti-synaptophysin immunocytochemistry. These mAbs indicated, respectively, a lack of intramuscular nerve processes and nerve terminal synaptic vesicles in treated animals. mAb $3 \mathrm{G} 2$ immunoreactivity was found at myotendinous junctions and within the sarcoplasm of many small-diameter fibers (Fig. 13). Thus, the extrasynaptic immunoreactivity of mAb $3 G 2$ seen in developing muscle fibers appears to be innervation independent.

\section{Discussion}

In this study, we utilized a monoclonal antibody, mAb $3 \mathrm{G} 2$, to identify and characterize a $41 \mathrm{kDa}$ protein concentrated at the rat neuromuscular and myotendinous junctions. At the neuromuscular junction, the $41 \mathrm{kDa}$ protein is found beneath the sarcolemma where it outlines the synaptic gutters and extends into spaces between gutters (Fig. 14). The $41 \mathrm{kDa}$ protein is also associated with sole plate nuclei and with Z-disks in the vicinity of the junction. Innervation is required to establish and maintain the localization of this protein to the neuromuscular junction. In addition, the $41 \mathrm{kDa}$ protein first appears at developing junctions during the first week after birth, as the junction is differentiating to its adult form.

\section{Relationship of the $41 \mathrm{kDa}$ protein to previously described subsarcolemmal proteins}

The catalog of proteins concentrated at the neuromuscular junction is extensive (for reviews, see Burden, 1987; Bloch and Pumplin, 1988; Froehner, 1991). To simplify a comparison with the $41 \mathrm{kDa}$ protein, the majority of these previously identified
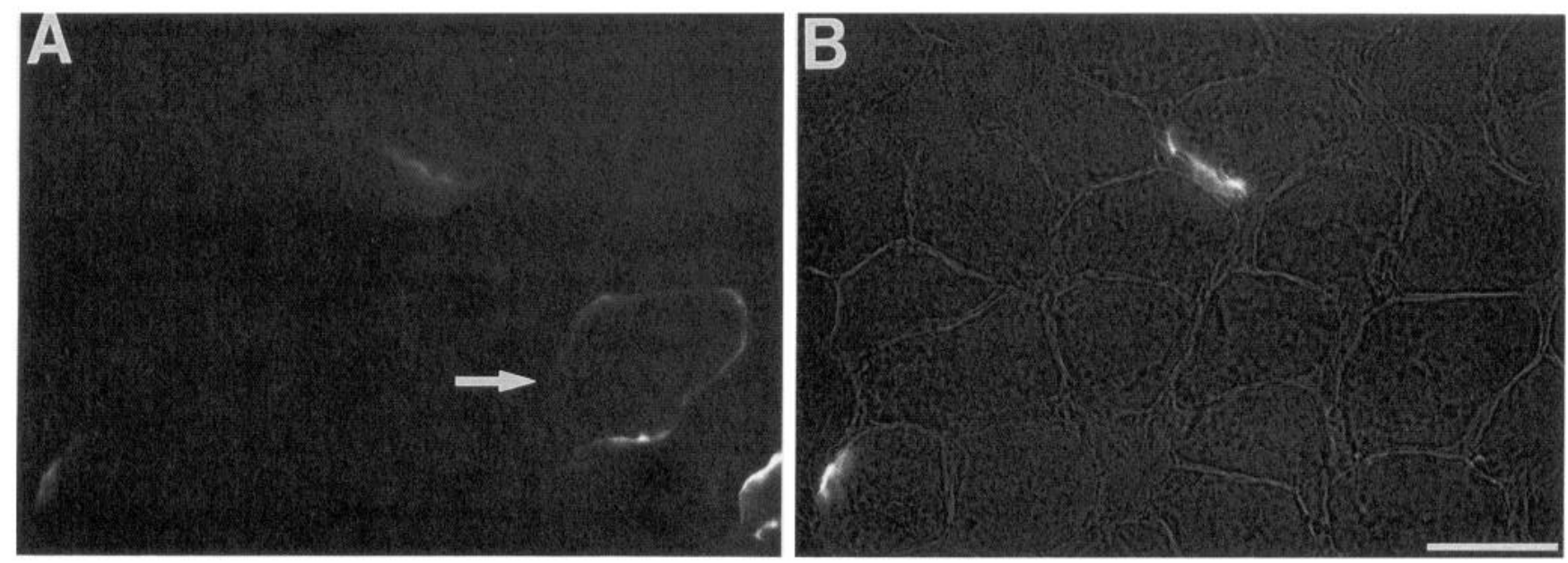

Figure 12. Immunoreactivity for $\mathrm{mAb} 3 \mathrm{G} 2$ is reestablished following reinnervation. A cross section of an adult soleus muscle made $13 \mathrm{~d}$ following nerve crush (when approximately $90 \%$ of the muscle fibers were reinnervated) was double labeled with mAb $3 \mathrm{G} 2$ followed by a fluorescein second antibody $(A)$ and with rBTX $(B)$. Some bright-field illumination has been added to $B$ to show the outlines of individual fibers. Immunoreactivity is detected at both rBTX-labeled junctions seen here. Additional immunoreactivity is detected about the entire sarcolemma of some fibers that are unlabeled by rBTX, one example of which is marked with an arrow in $A$. Scale bar, $25 \mu \mathrm{m}$. 

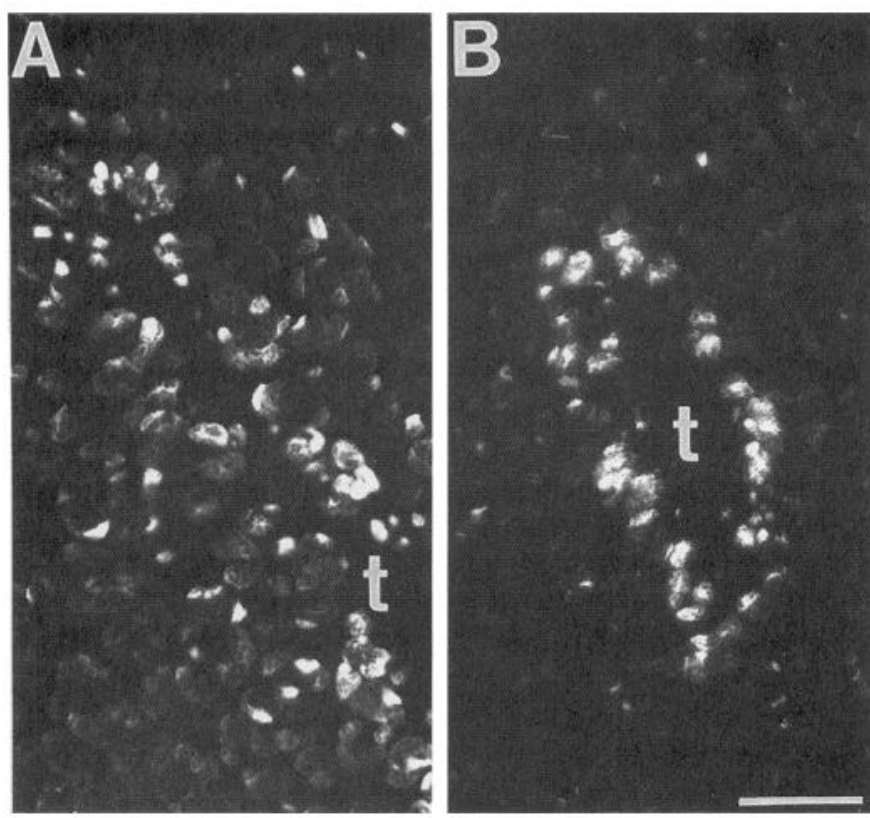

Figure 13. mAb $3 \mathrm{G} 2$ immunoreactivity at myotendinous junctions is innervation independent. Cross sections through the tibialis anterior muscles of normal $(A)$ and aneural $(B)$ E20 rat fetuses. Fibers at the myotendinous regions (adjacent to the central tendon, labeled $t$ ) are labeled with mAb 3G2. Scale bar, $50 \mu \mathrm{m}$.

junctional components have been grouped into three general categories: peripheral membrane proteins, intermediate filament proteins, and actin-associated proteins. Additional proteins that do not fit into these categories are also discussed below.

Peripheral membrane proteins. Peripheral membrane proteins are proteins that copurify with AChR-rich membrane vesicles isolated from Torpedo but that can be removed from these vesicles by treatment with alkaline buffers or with diiodosalicylate (Elliot et al., 1980). These include $43 \mathrm{kDa}, 58 \mathrm{kDa}, 87 \mathrm{kDa}$, and approximately $300 \mathrm{kDa}$ proteins. Antibodies to these proteins have been used to demonstrate their presence at the neuromuscular junction (Froehner et al., 1981, 1987; Burden, 1982; Froehner, 1984; Carr et al., 1989; Sealock et al., 1991).

We do not know whether the $41 \mathrm{kDa}$ protein in the present study could be isolated from rat muscle by treating AChR-rich vesicles with alkaline buffers or with diiodosalicylate. However, we believe the $41 \mathrm{kDa}$ protein is not one of the presently identified peripheral membrane proteins. One reason for this belief is the $41 \mathrm{kDa}$ protein differs in molecular mass from the identified proteins listed above. A second reason is differences in the immunocytochemical labeling of muscle fibers with $\mathrm{mAb}$ $3 \mathrm{G} 2$ versus with antibodies made to peripheral membrane proteins. All of these proteins except for the $43 \mathrm{kDa}$ protein are found at low levels in the extrajunctional muscle membrane (cf. Carr et al., 1989), in contrast to the junctional restriction observed for the $41 \mathrm{kDa}$ protein. The $43 \mathrm{kDa}$ protein differs from the $41 \mathrm{kDa}$ protein in its subcellular localization at the neuromuscular junction: the $43 \mathrm{kDa}$ protein exhibits a similar, if not identical, distribution to that of AChRs (Froehner et al., 1981; Froehner, 1984), whereas the distributions of the $41 \mathrm{kDa}$ protein and AChRs are not identical. An additional difference between the two is that the $41 \mathrm{kDa}$ protein is rapidly lost from the end plate upon denervation, whereas the $43 \mathrm{kDa}$ protein persists (Froehner et al., 1981).

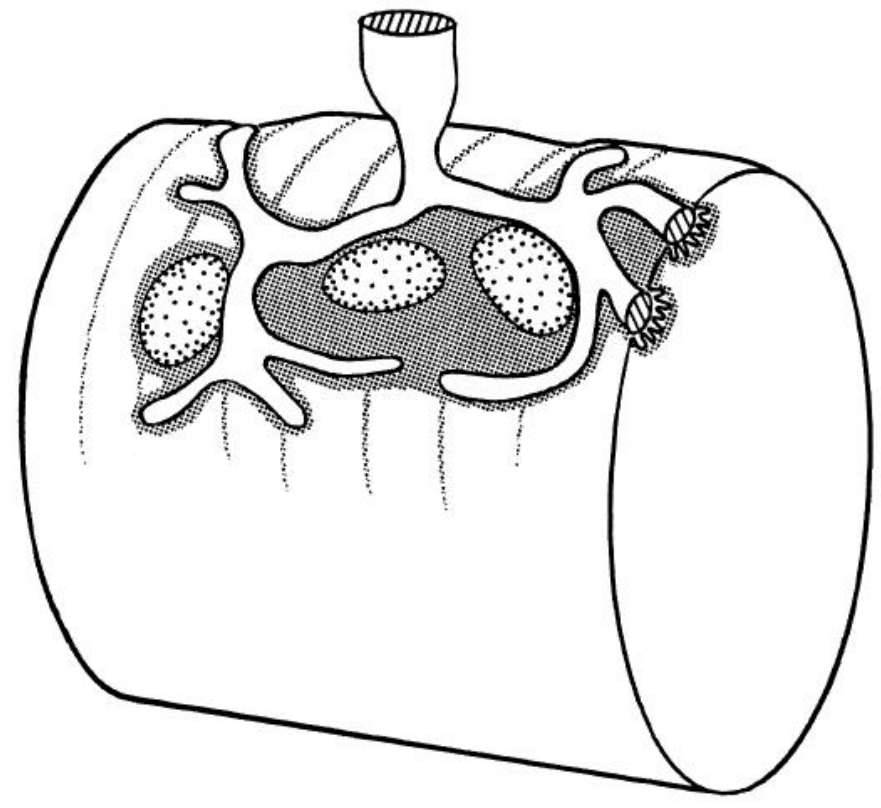

Figure 14. Schematic summary of the location of the epitope for mAb $3 \mathrm{G} 2$ at the rat neuromuscular junction. Only the junctional portion of a muscle fiber is shown. The fingerlike branches of the nerve terminal lie over the postsynaptic gutter, within which are numerous junctional folds (indicated at the right). $\mathrm{mAb} 3 \mathrm{G} 2$ immunoreactivity (gray shading) is found beneath and between the synaptic gutters and around the sole plate nuclei (dotted ovals). Immunoreactivity is also present at or near perijunctional Z-disks.

Intermediate filament proteins. Intermediate filaments are the approximately 10-nm-diameter fibrous components of the cytoskeleton that are characterized by an unusual stability and relative insolubility (Lazarides, 1980). Three intermediate filament components have been found at the neuromuscular junction: desmin (Sealock et al., 1989; Askanas et al., 1990), a 51 $\mathrm{kDa}$ protein isolated from Torpedo (Burden, 1982), and lamin B (Cartaud et al., 1989). Immunocytochemical localization of desmin at the rat neuromuscular junction indicates that it has a similar distribution to that of the $41 \mathrm{kDa}$ protein. Both are concentrated beneath and between synaptic gutters and appear to wrap sole plate nuclei (Sealock et al., 1989). However, we believe the $41 \mathrm{kDa}$ protein to be distinct from desmin for several reasons. First, the $41 \mathrm{kDa}$ protein is associated with perijunctional Z-disks only, whereas desmin is present at all Z-disks throughout the length of each muscle fiber (Lazarides, 1980). Furthermore, mAb $3 \mathrm{G} 2$ does not cross-react with rat desmin on immunoblots. Finally, preliminary results indicate that denervation does not alter the expression of desmin at the rat neuromuscular junction (S. H. Astrow, unpublished observations).

The $41 \mathrm{kDa}$ protein identified by $\mathrm{mAb} 3 \mathrm{G} 2$ is not likely to be either the mammalian homolog to the $51 \mathrm{kDa}$ protein or lamin $\mathrm{B}$. The $51 \mathrm{kDa}$ protein is found at extrajunctional sites in frog muscle and persists at end plates following denervation (Burden, 1982). Lamin B immunoreactivity appears coincident with AChR labeling and is also associated with nuclei outside the junction (Cartaud et al., 1989).

The relative insolubility of the $41 \mathrm{kDa}$ protein and its association with some desmin-containing structures suggest that this protein might be a member of the intermediate filament class. However, confirmation of this hypothesis will await further study. 
Actin-associated proteins. Stabilization of AChRs at the synapse is thought to be due to binding of AChRs to the subsarcolemmal cytoskeleton (Prives, 1982). Indeed, a non-myofibrillar isoform of actin and many actin-associated proteins (paxillin, $\beta$-spectrin, $\alpha$-actinin, vinculin, filamin, and talin) have been shown to be concentrated at the neuromuscular junction (see, e.g., Hall et al., 1981; Bloch and Hall, 1983; Sealock et al., 1986; Bloch and Morrow, 1989). Some of these proteins also appear to be concentrated at myotendinous junctions (Rochlin et al., 1989). However, none of these cytoskeletal proteins has a molecular mass of $41 \mathrm{kDa}$, and, unlike the $41 \mathrm{kDa}$ protein, actin-associated proteins can also be found outside the neuromuscular and myotendinous junctions, as well as in cells other than skeletal muscle fibers (Burridge et al., 1988). Moreover, in contrast to the $41 \mathrm{kDa}$ protein, many of these cytoskeletal proteins (cytoplasmic actin, $\alpha$-actinin, filamin, vinculin, and talin) persist at denervated neuromuscular junctions (Hall et al., 1981; Bloch and Hall, 1983; Sealock et al., 1986).

Other subsarcolemmal proteins. Aside from the proteins described above, an acetylated form of $\alpha$-tubulin has also been found in the subsynaptic sarcoplasm (Jasmin et al., 1990). In addition, the postsynaptic membrane also contains the $\mathrm{Na}^{+}$ channel and the protein ankyrin (Flucher and Daniels, 1989). Based on a comparison of molecular masses, the $41 \mathrm{kDa}$ protein is probably distinct from these proteins. Moreover, the $\mathrm{Na}^{+}$ channel is retained at denervated junctions (Caldwell and Milton, 1988).

Thus, by a combination of the criteria of molecular weight, subcellular distribution in relation to the $\mathrm{AChRs}$, presence/absence in the extrasynaptic sarcolemma, and response to denervation, the $41 \mathrm{kDa}$ protein recognized by $\mathrm{mAb} 3 \mathrm{G} 2$ appears to be a novel postsynaptic protein.

\section{Possible functions of the $41 \mathrm{kDa}$ protein at the neuromuscular junction}

The close association of the $41 \mathrm{kDa}$ protein with the differentiated structure of the adult neuromuscular junction invites speculation as to its function. Clearly this protein cannot establish or maintain the concentration of AChRs at the junction. First, the $41 \mathrm{kDa}$ protein becomes associated with junctions only late in development, following the establishment of high densities of receptors. Second, the $41 \mathrm{kDa}$ protein disappears from junctions following their denervation whereas the high density of receptors is maintained (Frank et al., 1976). Other differentiated features of the adult neuromuscular junction, including the presence of junctional folds, the concentration of $\mathrm{Na}^{+}$channels, and the accumulation of sole plate nuclei, are also maintained in the denervated, adult junction (Miledi and Slater, 1968; Caldwell and Milton, 1988; Rich and Lichtman, $1989 \mathrm{a})$. Thus, it is unlikely that the $41 \mathrm{kDa}$ protein plays any essential role in the maintenance of these features.

While the appearance of the $41 \mathrm{kDa}$ protein at the neuromuscular junction does not appear to be correlated with any of the postsynaptic specializations of the junction, a correlation does exist between synaptic $41 \mathrm{kDa}$ expression and the presence of the nerve. A second observation that may bear on the function of the $41 \mathrm{kDa}$ protein is its association with the Z-disk of sarcomeres both at the neuromuscular and myotendinous junctions. At either site, stabilizing connections to the extracellular matrix are thought to be necessary to maintain structural integrity during muscle contraction, such that the fibers are not pulled away from the tendon (at the myotendinous junction) or from the nerve (at the neuromuscular junction). Along these lines, we suggest that the $41 \mathrm{kDa}$ protein may function at the synapse as a component of a chain of proteins that links the nerve terminal to the muscle fiber.

Also of interest in regard to the function of the $41 \mathrm{kDa}$ protein is its developmental regulation. The appearance of the $41 \mathrm{kDa}$ protein at the neuromuscular junction lags behind the clustering of AChRs, suggesting that the $41 \mathrm{kDa}$ antigen does not play a role in the early events of synaptic differentiation. However, at the time the $41 \mathrm{kDa}$ protein appears at neuromuscular junctions, extensive remodeling of these synaptic connections is occurring. At this time, the early polyneuronal innervation of individual muscle fibers is being eliminated and one nerve terminal is being competitively selected for maintenance (Brown et al., 1976). Recent experimental evidence shows that postsynaptic events in the muscle fiber play a crucial role in the maintenance of nerve terminals (Rich and Lichtman, 1989a,b). It is intriguing to speculate that the $41 \mathrm{kDa}$ protein could play some role in the maintenance of one nerve terminal at the expense of others. Clearly, more experimentation will be required to substantiate these suggestions and to establish the function of this protein.

\section{References}

Askanas V, Bornemann A, Engel WK (1990) Immunocytochemical localization of desmin at human neuromuscular junctions. Neurology 40:949-953.

Bennett MR, Pettigrew AG (1974) The formation of synapses in striated muscle during development. J Physiol (Lond) 241:51 5-545.

Bloch RJ, Hall ZW (1983) Cytoskeletal components of the vertebrate neuromuscular junction: vinculin, $\alpha$-actinin, and filamin. J Cell Biol 97:217-223.

Bloch RJ, Morrow JS (1989) An unusual $\beta$-spectrin associated with clustered acetylcholine receptors. J Cell Biol 108:481-493.

Bloch RJ, Pumplin DW (1988) Molecular events in synaptogenesis: nerve-muscle adhesion and postsynaptic differentiation. Am J Physiol 254:C345-C364.

Brown MC, Jansen JKS, Van Essen D (1976) Polyncuronal inncrvation of skeletal muscle in new-born rats and its elimination during maturation. J Physiol (Lond) 261:387-422.

Burden S (1982) Identification of an intracellular postsynaptic antigen at the frog neuromuscular junction. J Cell Biol 94:521-530.

Burden SJ (1987) The extracellular matrix and subsynaptic sarcoplasm at nerve-muscle synapses. In: The vertebrate neuromuscular junction (Salpeter MM, ed), pp 163-186. New York: Liss.

Burridge K, Fath K, Kelly T, Nuckolis G, Turner C (1988) Focal adhesions: transmembrane junctions between the extracellular matrix and the cytoskeleton. Annu Rev Cell Biol 4:487-525.

Caldwell JH, Milton RL (1988) Sodium channel distribution in normal and denervated rodent and snake skeletal muscle. J Physiol (Lond) 401:145-161.

Carr C, Fischbach GD, Cohen JB (1989) A novel 87,000- $M_{r}$ protcin associated with acetylcholine receptors in Torpedo electric organ and vertebrate skeletal muscle. J Cell Biol 109:1753-1764.

Cartaud A, Courvalin JC, Ludosky MA, Cartaud J (1989) Presence of a protein immunologically related to lamin B in the postsynaptic membrane of Torpedo marmorata electrocyte. J Cell Biol 109:17451752.

Condon K, Silberstein L, Blau HM, Thompson WJ (1990a) Development of muscle fiber types in the prenatal rat hindlimb. Dev Biol 138:256-274.

Condon K, Silberstein L, Blau HM, Thompson WJ (1990b) Differentiation of fiber types in aneural musculature of the prenatal rat hindlimb. Dev Biol 138:275-295.

Desaki J, Uehara Y (1987) Formation and maturation of subneural apparatuses at neuromuscular junctions in postnatal rats: a scanning and transmission electron microscopical study. Dev Biol 119:390 401 .

Elliot J, Blanchard SG, Wu W, Miller J, Strader CD, Hartig P, Moore H, Racs J, Raftery MA (1980) Purification of Torpedo californica 
post-synaptic membranes and fractionation of their constituent proteins. Biochem J 185:667-677.

Flucher BE, Daniels MP (1989) Distribution of $\mathrm{Na}^{+}$channels and ankyrin in neuromuscular junctions is complementary to that of acetylcholine receptors and the $43 \mathrm{kD}$ protein. Neuron 3:163-175.

Frank E, Gautvik K, Sommerschild H (1976) Persistence of junctional acetylcholine receptors following denervation. Cold Spring Harbor Symp Quant Biol 40:275-281.

Froehner SC (1984) Peripheral proteins of postsynaptic membranes from Torpedo electric organ identified with monoclonal antibodies. J Cell Biol 99:88-96.

Froehner SC (1991) The submembrane machinery for nicotinic acetylcholine receptor clustering. J Cell Biol 114:1-7.

Froehner SC, Gulbrandsen V, Hyman C, Jeng AY, Neubig RR, Cohen JB (1981) Immunofluorescence localization at the mammalian neuromuscular junction of the $M, 43,000$ protein of Torpedo postsynaptic membranes. Proc Natl Acad Sci USA 78:5230-5234.

Froehner SC, Murnane AA, Tobler M, Peng HB, Sealock R (1987) A postsynaptic $M, 58,000(58 \mathrm{~K})$ protein concentrated at acetylcholine receptor-rich sites in Torpedo electroplaques and skeletal muscle. $\mathrm{J}$ Cell Biol 104:1633-1646.

Hall DE, Frazer KA, Hann BC, Reichardt LF (1988) Isolation and characterization of a laminin-binding protein from rat and chick muscle. J Cell Biol 107:687-697.

Hall ZW, Lubit BW, Schwartz JH (1981) Cytoplasmic actin in postsynaptic structures at the neuromuscular junction. J Cell Biol 90:789792.

Harris AJ (1981) Embryonic growth and innervation of rat skeletal muscles. I. Neural regulation of muscle fibre numbers. Philos Trans R Soc Lond [Biol] 293:257-277.

Hockfield S (1987) A Mab to a unique cerebellar neuron generated by immunosuppression and rapid immunization. Science 237:67-70.

Huiatt TW, Robson RM, Arakawa N, Stromer MH (1980) Desmin from avian smooth muscle. J Biol Chem 255:6981-6989.

Jasmin BJ, Changeux J-P, Cartaud J (1990) Compartmentalization of cold-stable and acetylated microtubules in the subsynaptic domain of chick skeletal muscle fibre. Nature 344:673-675.

Laemmli UK (1970) Cleavage of structural proteins during assembly of the head of bacteriophage T4. Nature 227:680-685.

Lazarides E (1980) Intermediate filaments as mechanical integrators of cellular space. Nature 283:249-256.

Littlefield JW (1964) Selection of hybrids from matings of fibroblast in vitro and their presumed recombinants. Science 145:709-710.

Lomo $T$ (1987) Formation of ectopic neuromuscular junctions: role of activity and other factors. In: The neural and molecular bases of learning (Changeaux J-P, Konishi M, eds), pp 359-374. New York: Wiley.

Miledi R, Slater CR (1968) Electrophysiology and electron-microscopy of rat neuromuscular junctions after nerve degeneration. Proc R Soc Lond [Biol] 169:289-306.

Miledi R, Slater CR (1970) On the degeneration of rat neuromuscular junctions after nerve section. J Physiol (Lond) 207:507-528.

Prives J, Fulton AB, Penman S, Daniels MP, Christian CN (1982) Interaction of the cytoskeletal framework with acetlycholine receptors on the surface of embryonic muscle cells in culture. J Cell Biol 92: 231-236.

Rees D (1978) A non-phosphate-buffered physiological saline for in vitro electrophysiological studies on the mammalian neuromuscular junction. J Physiol (Lond) 278:8-9P.

Rich MM, Lichtman JW (1989a) In vivo visualization of pre- and postsynaptic changes during synapse elimination in reinnervated mouse muscle. J Neurosci 9:1781-1805.

Rich MM, Lichtman JW (1989b) Motor nerve terminal loss from degenerating muscle fibers. Neuron 3:677-688.

Rochlin MW, Chen Q, Tobler M, Turner CE, Burridge K, Peng HB (1989) The relationship between talin and acetylcholine receptor clusters in Xenopus muscle cells. J Cell Sci 92:461-472.

Salpeter MM (1987) Vertebrate neuromuscular junctions: general morphology, molecular organization, and functional consequences. In: The vertebrate neuromuscular junction (Salpeter MM, ed), pp 154. New York: Liss.

Sealock R, Paschal B, Beckerle M, Burridge K (1986) Talin is a postsynaptic component of the rat neuromuscular junction. Exp Cell Res 163:143-150.

Sealuck R, Murnane AA, Paulin D, Froehner SC (1989) Immunochemical identification of desmin in Torpedo postsynaptic membranes and at the rat neuromuscular junction. Synapse 3:315-324.

Sealock R, Butler MH, Kramarcy NR, Gao K-X, Murnane AA, Douville K, Froehner SC (1991) Localization of dystrophin relative to acetylcholine receptor domains in electric tissue and adult and cultured skeletal muscle. J Cell Biol 113:1133-1144.

Seiler S, Fleischer S (1982) Isolation of plasma membrane vesicles from rabbit skeletal muscle and their use in ion transport studies. J Biol Chem 257:13862-13871.

Shear CR, Bloch RJ (1985) Vinculin in subsarcolemmal densities in chicken skeletal muscle: localization and relationship to intracellular and extracellular studies. J Cell Biol 101:240-256.

Tzartos SJ, Rand DE, Einarson BL, Lindstrom JM (1981) Mapping of surface structures of Electrophorus acetylcholine receptor using monoclonal antibodies. J Biol Chem 256:8635-8645. 